\title{
Accounting Treatment of Inherent Versus Incentive Uncertainties and the Capital Structure of the Firm
}

\author{
Pierre Jinghong Liang \\ Tepper School of Business \\ Carnegie Mellon University \\ Xiao-Jun Zhang \\ Haas School of Business \\ University of California, Berkeley
}

March 2005

Suggestions from Anil Arya, Joel Demski, John Fellingham, Jon Glover, Karl Hackenbrack, Thomas Hemmer, Burton Hollifield, Yuji Ijiri, Bjorn Jorgensen, Jerry Salamon, Nathan Stuart, Shyam Sunder, participants at the 2001 Carnegie Mellon University conference on the "Intellectual Foundations of Accounting," the 2002 EIASM Workshop on Accounting and Economics V in Madrid, Spain, and the workshops at Carnegie Mellon University, University of Chicago, University of Florida, and Ohio State University, and an anonymous referee, are gratefully acknowledged. 


\begin{abstract}
This paper studies the accounting treatment of uncertainty and how it affects a firm's capital structure. We distinguish two sources of uncertainty that raise reliability concerns: inherent uncertainty and incentive uncertainty. By inherent uncertainty, we refer to uncertainty about the quality of raw information regarding future cash flows. By incentive uncertainty, we refer to uncertainty of the quality of accounting numbers conveying the raw information. We explore features of accounting that can effectively deal with these two types of uncertainties in order to aid in the debt-equity decision of the firm. To handle inherent uncertainty, preferable accounting involves flexible revenue/expense recognition rules that recognize more profit when the uncertainty level is low. To deal with incentive uncertainty, a stringent revenue/expense recognition rule may be desirable to fend off potential accounting abuses.

Inflexible accounting rules cause a firm's financing choices to deviate from what would be obtained with complete information. Given any accounting rule, an information environment with a lower (higher) uncertainty regarding future cash inflows leads to higher (lower) expected debt financing. This is because assessed default risk is increasing in the uncertainty of future cash inflows, holding the uncertainty of the outflows constant.
\end{abstract}




\section{Accounting Treatment of Inherent Versus Incentive Uncertainties and the Capital Structure of the Firm}

\section{Introduction}

This paper studies the accounting treatment of uncertainty and how it affects a firm's capital structure. Our analysis distinguishes two sources of uncertainty that raise reliability concerns: inherent uncertainty and incentive uncertainty. By inherent uncertainty, we refer to uncertainty about the quality of raw information regarding future cash flows. In particular, we examine the uncertainty about hardness (or softness) of the raw information. By incentive uncertainty, we refer to uncertainty about the quality of accounting numbers conveying the raw information. In particular, we consider the uncertainty over the credibility of accounting numbers due to the potential management misrepresentation of the underlying raw information. Accounting features, such as the revenue/expense recognition criterion, respond to such uncertainties and, as a result, accommodate or restrict the supply of information that affects the firm capital structure decisions.

In the presence of the inherent uncertainty, we show that a flexible accounting rule, such as historical cost accounting with multiple permissible revenue recognition methods, induces more efficient financing decisions and is thus preferable to a stringent accounting policy, such as cash accounting or even fair value accounting. The primary reason is that flexible accounting allows the recognition choice itself to convey information about information quality (e.g., nonrecognition implies the raw information is too soft). In contrast, in the presence of both inherent and incentive uncertainties, the firm is better off with a stringent accounting policy, such as historical cost accounting with only one permissible revenue recognition method. This is because stringent accounting mitigates the adverse selection problem in the capital market. 
In a single firm setting, we model a debt-equity choice that involves a trade-off between the expected bankruptcy cost of debt and the opportunity cost of equity. The trade-off generates a demand for information regarding future cash inflows and outflows, especially the inherent uncertainty thereof. In particular, it is important to distinguish the state where a firm receives soft information or no information at all (modeled as having a posterior distribution which is the same as the prior distribution) from the state where the firm receives certain hard information (modeled as having a posterior with the same mean as the prior but with a smaller range). That is to say, the resolution of inherent uncertainty matters from a capital structure standpoint.

In a benchmark information environment with no inherent uncertainties (i.e., the raw information is always hard), we show that a standard fair value accounting rule suffices to induce an optimal financing arrangement and to achieve economic efficiency. Under this rule, revenues and expenses are recognized before the actual cash receipts or outlays.

In the presence of inherent uncertainties, we show that the desirable accounting method involves flexible revenue/expense recognition rules in order to effectively communicate the needed information. When the information about future cash flows is soft or absent, the accounting method deviates from the standard fair value accounting to reflect the higher remaining uncertainty involved. In general, fewer future profits/losses are recognized in the presence of soft information or in the absence of any information. ${ }^{1}$ No single revenue recognition policy (e.g., fair value accounting or cash basis accounting) is sufficient to convey the underlying information in most cases. Instead, the desirable accounting method will allow

\footnotetext{
1 Similarly, the FASB Statement of Concepts No.5 also recognizes the "unavailability and unreliability of information" as salient features of accounting's information environment, which may delay accounting recognition of the information. See FASB Statement of Concepts No. 5 (1984, para. 77.)
} 
for flexibility so that profits are recognized at different points in the transaction cycle. In addition, these recognition rules should reflect the uncertainty of future cash inflows as well as outflows, rather than the uncertainty of net future cash flows.

Adding another layer of uncertainties to the mix, we consider incentive uncertainties which are introduced into the accounting process by potential management misrepresentation. We show that the way in which accounting handles uncertainty becomes quite different in the presence of both inherent and incentive uncertainties. More specifically, we consider a setting where the manager acts on behalf of the equity investor and where he has an incentive to withhold critical information when negotiating the credit terms. The debt investor, anticipating this incentive, would charge a higher premium when suspecting such abuses. The higher premium, in turn, forces many good firms out of the credit market. We show that in such cases all parties may be better off, ex ante, by adopting a stringent accounting rule.

We also study the impact of the above accounting characteristics on the firm capital structure. The stringent accounting rule, which is used to fend off potential management abuse, causes the firm's financing choices to deviate from ideal ones under the condition of complete information. Finally, our analysis reveals how a firm's information environment affects the equilibrium financing choices. When information about future resource inflows is easier to obtain relative to future resource outflows, debt-financing will more likely be used. In contrast, when there is more uncertainty about future revenue relative to costs, equity-financing will more likely be used. This is because assessed default risk is increasing in the uncertainty of future cash inflows, holding the uncertainty of the outflows constant. 
A fundamental connection between accounting income-measurement concepts and the information for economic decisions has been suggested in the accounting literature. ${ }^{2}$ Demski and Sappington (1990) construct an accounting model which features (abstract) accruals and a valuation language. They identify the conditions under which accounting income measurement fully reveals underlying information about a firm. We expand their setting by introducing a specific decision context (debt-equity choices) and the explicit accounting features of revenue and expense recognition policies. The matching property of accrual accounting has been studied by Rogerson (1997) and Reichelstein (1997) in a project-selection setting, as well as by Ohlson and Zhang (1998) in a firm-valuation setting. In both settings, matching allows accounting income to be an efficient aggregator of the underlying information for a particular economic or measurement purpose. In recognition studies, one policy is shown to dominate another in a stewardship setting (Liang 2000, Dutta and Zhang 2001), in an operating setting (Kirshenheiter 1999), or in a combination of consumption timing and stewardship settings (Antle and Demski 1989). In these studies, various recognition policies regulate the flow of underlying information, which affects economic choices and, thus, equilibria. In this paper, we focus on a different economic trade-off (debt-equity) and on the information properties of underlying information (hard-vs-soft information and inherent-vs-incentive uncertainty). As a result, the desirable accounting method in our setting has different characteristics from those in earlier studies. In particular, a key finding is the importance of allowing for multiple recognition rules based on the properties of the underlying accounting events.

\footnotetext{
2 The income-measurement and economic information-content perspectives are the two dominant schools of thought in the US. The former is emphasized by numerous writers such as Paton (1922), Paton and Littleton (1940), and Ijiri (1975) while the latter is emphasized by Demski and Feltham (1976), Christensen and Demski (2002), and Christensen and Feltham (2002).
} 
Furthermore, the issue of "flexible versus stringent" accounting rules also has a long and rich history in the accounting literature (e.g., Catlett 1964, Brown 1966, Estes and Brown 1966). More recently, Dye and Verrecchia (1995) study the issue from a contracting perspective and identify sufficient conditions for a flexible expenses recognition rule to dominate a stringent one. Flexible expenses recognition, as they show, leads to better control of the manager's moral hazard problem and hence increases the owner's net profit. We examine this issue from a (capital) valuation perspective and show that a stringent accounting rule is generally more welfare enhancing in the presence of adverse selection in the credit market. The reason that our finding is different from that of Dye and Verrecchia (1995) is two-fold. First, since we do not consider the internal moral hazard problem of corporate managers, the advantage of flexible rules in fulfilling a stewardship role (as identified in Dye and Verrecchia 1995) is absent from our paper. Second, in a valuation context with incentive uncertainty and soft information, a stringent rule mitigates the adverse selection problem in the credit market. ${ }^{3}$ This adverse selection aspect is not modeled in Dye and Verrecchia (1995). Our study also emphasizes how information properties affect accounting methods in the absence of any incentive issues. For instance, the existence of soft information per se does not render flexible rules less desirable. In a setting with only inherent uncertainty due to the presence of soft information, a flexible rule is still preferable to a stringent rule. ${ }^{4}$ However, when soft information creates incentive uncertainty

\footnotetext{
3 Evidence is considered to be "soft" when its interpretation differs across various parties. See Kirschenheiter (2002) for related discussion on "soft" and "hard" information and "honest disagreement."

4 This conclusion, although similar to that of Dye and Verrecchia (1995), is based on fundamentally different reasoning. The preferability of a flexible rule is not due to the incentive consideration associated with the application process of the accounting rules. Instead, it is due to the added capacity of the accounting rules themselves.
} 
with respect to the credibility of accounting reports, a stringent accounting rule may be more desirable.

Our study also contributes to the literature on capital structure. Since the seminal work of Modigliani and Miller (1958), various theories have been proposed to explain a firm's debtequity choices. For example, the tradeoff theory predicts that an optimal debt level balances the tax benefit against the financial-distress cost of debt (Baxter 1967, Chen 1979, Kraus and Litzenberger 1973). The pecking order theory emphasizes the cost of information asymmetry between managers and investors (Myers and Majluf 1984). Hart (1995) offers an explanation of debt which is based on the theory of incomplete contracts. Our paper adds to the literature by demonstrating how a firm's information environment (hard vs. soft information and inherent vs. incentive uncertainty) affects the equilibrium financing choices. In addition, we demonstrate how the conflict between managers and debt holders affects a firm's capital structure through its impact on accounting principles.

The remainder of the paper proceeds as follows. Section 2 outlines the economic model with an endogenous demand for information. Section 3 describes the information environment and the full information benchmark. In sections 4-7, we examine the impact of inherent and incentive uncertainty on desirable accounting policies and optimal financing choices. Section 8 concludes the paper.

\section{The Economic Structure and Demand for Information}

\subsection{Equity Investor}

Consider an economy in which a risk-neutral equity investor (or owner) owns a twoperiod stochastic production technology. On date 0 , the technology requires an initial monetary 
investment, a cash outflow denoted $\mathrm{x}_{1}>0$, which is known with certainty. We assume the equity investor provides the funding for $\mathrm{x}_{1}$, which is immediately spent on the firm's operations. On date 1 , a random cash inflow $\mathrm{y}_{1}>0$ is realized. At the start of the second period, the project requires a second investment, denoted $\mathrm{x}_{2}>0$, which is followed by a second cash inflow $\mathrm{y}_{2}>0$, realized on date 2 . We assume the probability distributions of $\mathrm{y}_{1}, \mathrm{x}_{2}$, and $\mathrm{y}_{2}$ are mutually independent. Define $\mathrm{k} \equiv \mathrm{x}_{2}-\mathrm{y}_{1}$ as the extra funding needed for the second period. Assume $\mathrm{k}>$ 0 and $k \in\{0, X / 3,2 X / 3, X\}$ with $X>0, \operatorname{Prob}(k=0)=\operatorname{Prob}(k=X / 3)=\operatorname{Prob}(k=2 X / 3)=\operatorname{Prob}(k=X)=$ $1 / 4$, and $\mathrm{y}_{2} \in\left\{\mathrm{Y}_{\mathrm{L}}, \mathrm{Y}_{\mathrm{H}}\right\}$ with $\mathrm{Y}_{\mathrm{H}}>\mathrm{Y}_{\mathrm{L}}>0, \operatorname{Prob}\left(\mathrm{y}_{2}=\mathrm{Y}_{\mathrm{L}}\right)=\operatorname{Prob}\left(\mathrm{y}_{2}=\mathrm{Y}_{\mathrm{H}}\right)=1 / 2 .{ }^{5}$ These strong assumptions are made simply to highlight the intuition behind the results; all of our results can be generalized to cases where $\mathrm{k}$ and $\mathrm{y}_{2}$ have other (and perhaps more realistic) probability or density functions. See Figure 1 on page 10 for a timeline of the model.

The project is a single venture. The initial investment $\left(\mathrm{x}_{1}\right)$ is not scalable and all future cash inflows and outflows are irreversible. ${ }^{6}$ The firm must secure enough funds by date 1 to cover all possible realizations of $\mathrm{k}$. We call this the operating constraint. ${ }^{7}$

5 Modeling $\mathrm{k}$, as opposed to $\mathrm{x}_{2}$, has the advantage of analytic ease, without any loss of generality, For a given distribution of $\mathrm{y}_{1}$, there is a one-to-one mapping between the distribution of $\mathrm{x}_{2}$ and that of $\mathrm{k}$. The restriction $\mathrm{k}>0$ is simply a statement that $\mathrm{x}_{2}$ is greater than $\mathrm{y}_{2}$ state-by-state. There is no extra restriction by using $\mathrm{k}$.

6 As such we assume that the owner cannot bypass the first period to invest in the second period only, nor can the owner liquidate the project on date 1 . The firm has a long-term commitment such that once the initial investment is made, the firm must follow through and complete the project.

7 Alternatively, one can assume that a shortage of operating funds incurs a cost and the optimal capital infusion is the amount that equates the marginal cost of fund-shortage to the marginal benefit of alternative use of the fund. Under this more general assumption, the funding source (debt or equity) may affect the optimal amount of funding. Our operating constraint, which is a simplification of the general assumption, implies that any such shortage is prohibitively costly. This allows the paper to focus on the other tension on funding sources (debt or equity). 
Since we assume $\mathrm{k}>0$, the operating constraint requires additional funds to flow into the firm by date 1 . There are two sources of funding: equity and debt. We use

$$
\mathrm{e} \in \mathbb{R}^{+}
$$

to denote the owner's equity contribution to the firm on date 1. To create an economic trade-off, we assume that any unused funds (over and above the realized k) earn a zero return, and the owner's alternative use of the funds induces a discount rate, $r>0$.

\subsection{Debt Investor}

As an alternative funding source, a risk-neutral debt investor (or banker), who has enough funds to finance the firm for the second period, is also available on date $1 .^{8}$ To create gains to trade, we assume that the banker's discount rate (for bankruptcy-free loans) is zero. Denote the amount of debt raised for the second period by

$$
\mathrm{d} \in \mathbb{R}^{+} .
$$

We assume there is no incentive to borrow more than necessary to fund a dividend payment. In exchange for receiving $\mathrm{d}$ from the banker, the firm promises a repayment on date 2, denoted $\mathrm{Q}$. The actual payment to the banker at $\mathrm{t}=2$, denoted $\mathrm{P}$, is given by

$$
\mathrm{P}= \begin{cases}\mathrm{Q} & \text { if } \mathrm{z}>\mathrm{Q} \\ \mathrm{z} & \text { if } \mathrm{z}<\mathrm{Q}\end{cases}
$$

where $\mathrm{z} \equiv \mathrm{y}_{1}+\mathrm{d}+\mathrm{e}-\mathrm{x}_{2}+\mathrm{y}_{2}=\mathrm{d}+\mathrm{e}-\mathrm{k}+\mathrm{y}_{2}$, which represents the firm's available funds on date 2. If the firm defaults (i.e., $\mathrm{z}<\mathrm{Q}$ ), the bankruptcy triggers a dead-weight loss, denoted by

\footnotetext{
8 We can prove that allowing debt-financing on date 0 complicates the analysis but would not change the gist of our results. Also, we assume the firm may engage in a single loan agreement at date 1, not a series of loans with different terms. We conjecture that allowing that possibility does not add new major insights because at the margin, the last in this series of loans would be subjected to the same economic tensions.
} 
$\mathrm{C}$, which is paid (to the court) by the banker. ${ }^{9}$ We assume that $\mathrm{C}$ is a linear function of $\mathrm{d}$, the actual amount borrowed, (i.e., $\mathrm{C}=\mathrm{c} \cdot \mathrm{d}$, where $\mathrm{c}$ is a known positive cost parameter). The banking market is competitive such that, conditional on public information, the expected repayment to the banker is equal to the amount borrowed plus expected bankruptcy costs. We call this the financing constraint.

\subsection{Firm's Financing Problem}

On date 1 , the firm chooses the best combination of equity (e) and debt (d) to maximize the expected NPV of the project. Denote $\Omega$ as the set of accounting information available on date 1 . We assume that $\Omega$ is the product of an accounting system which converts a set of underlying raw information, including cash flows and other primitive signals, into stylized accounting numbers such as revenue and expenses. Both equity and debt investors have perfect understanding of the accounting system and homogenous beliefs about the properties of cash flows and other primitive signals. Throughout the paper, we assume that $\Omega$ is publicly observable and always includes realized cash flows $\mathrm{x}_{1}$ and $\mathrm{y}_{1}$. Depending on the accounting policy, $\Omega$ may also include non-cash components, such as a deferral or accrual that, in turn, may convey other primitive signals (which we model in later sections 3, 4 and 5). Figure 1 provides a timeline of the model.

\footnotetext{
9 The existence of the non-trivial bankruptcy cost is an important and critical assumption, not which party pays the cost. The same results are obtained if we assume the owner pays the cost with slightly more notation and analytical complexity.
} 


\begin{tabular}{|c|c|c|c|c|}
\hline & \multicolumn{4}{|c|}{ Figure 1: Time Line of the Model } \\
\hline & Date 0 & 1- & $\left.\right|^{1} \quad 1+$ & 2 \\
\hline Operating Cash Flows & $-\mathrm{x}_{1}$ & $+\mathrm{y}_{1}$ & $-\mathrm{x}_{2}=-\left(\mathrm{y}_{1}+\mathrm{k}\right)$ & $+\mathrm{y}_{2}$ \\
\hline Financing Cash Flows & $+\mathrm{x}_{1}$ & & $\begin{array}{l}+\mathrm{e} \\
+\mathrm{d}\end{array}$ & $\begin{array}{l}\text { If } \mathrm{z}>\mathrm{Q},-\mathrm{P}=-\mathrm{Q} \\
\text { If } \mathrm{z}<\mathrm{Q},-\mathrm{P}=-\mathrm{z} \\
\text { where } \mathrm{z} \equiv \mathrm{e}+\mathrm{d}-\mathrm{k}+\mathrm{y}_{2}\end{array}$ \\
\hline Accounting information & & & $\Omega$ & \\
\hline
\end{tabular}

On date 1 , the optimal financing arrangement is a solution to the following optimization program:

Choose $\langle\mathrm{e}(\Omega), \mathrm{d}(\Omega), \mathrm{Q}(\Omega)\rangle$ to maximize

$$
\sum_{\Omega} \sum_{\mathrm{k}, \mathrm{y}_{2}} \mathrm{~V}(\mathrm{e}, \mathrm{d}, \mathrm{Q} \mid \Omega) \operatorname{Prob}\left(\mathrm{y}_{2}, \mathrm{k} \mid \Omega\right) \operatorname{Prob}(\Omega)
$$

subject to:

$$
\begin{aligned}
& \mathrm{d}(\Omega)+\mathrm{e}(\Omega) \geq \text { supremium }\{\operatorname{support}(\mathrm{k}) \mid \Omega\} \\
& \mathrm{E}[\mathrm{P} \mid \mathrm{e}(.), \mathrm{d}(.), \mathrm{Q}(.), \Omega]=\mathrm{d}(\Omega)+\operatorname{Prob}(\mathrm{z}<\mathrm{Q} \mid \Omega) \cdot \mathrm{c} \cdot \mathrm{d}(\Omega)
\end{aligned}
$$

where $\mathrm{V}(\mathrm{e}, \mathrm{d}, \mathrm{Q} \mid \Omega) \equiv-\mathrm{e}(\Omega)+\left[\mathrm{e}(\Omega)+\mathrm{d}(\Omega)+\mathrm{y}_{2}-\mathrm{k}-\mathrm{P}(\mathrm{z}, \mathrm{Q})\right] \gamma$ and the discount factor is denoted as $\gamma \equiv 1 /(1+r)$. The function V(.) represents the NPV of the firm's future cash flows, evaluated on date 1 . Its first component, $-\mathrm{e}($.$) , is the current contribution to the firm by the$ equity investor. The second component, $\left[\mathrm{e}()+.\mathrm{d}()+.\mathrm{y}_{2}-\mathrm{k}-\mathrm{P}\right] \gamma$, is the discounted value of the date-2 net cash flow. ${ }^{10}$

10 Note that $x_{1}$ is a sunk cost on date 1 and is therefore excluded and $\mathrm{y}_{1}$ is realized before the debt or equity funding is chosen. So, the expectation is taken over $\mathrm{k}$ and $\mathrm{y}_{2}$. 
We assume that a solution to the linear program exists and denote $\operatorname{EV}(\Omega)$ as the expected date- 1 value of cash flows given the best financing arrangement, conditional on $\Omega$. That is

$$
\begin{aligned}
\operatorname{EV}(\Omega) & =\sum_{\mathrm{k}, \mathrm{y}_{2}} \mathrm{~V}\left(\mathrm{e}^{*}(\Omega), \mathrm{d}^{*}(\Omega), \mathrm{Q} *(\Omega)\right) \operatorname{Pr} \mathrm{ob}\left(\mathrm{k}, \mathrm{y}_{2} \mid \Omega\right) \\
& =-\mathrm{e}^{*}(\Omega)+\left[\mathrm{e}^{*}(\Omega)+\mathrm{d}^{*}(\Omega)+\mathrm{E}\left[\mathrm{y}_{2} \mid \Omega\right]-\mathrm{E}[\mathrm{k} \mid \Omega]-\mathrm{E}[\mathrm{P} \mid \Omega]\right] \gamma .
\end{aligned}
$$

Since the financing constraint is satisfied, i.e., $E[P \mid \Omega]=d^{*}(\Omega)+\beta(\Omega) c d^{*}(\Omega)$, we have

$$
\mathrm{EV}(\Omega)=\left[\mathrm{E}\left[\mathrm{y}_{2} \mid \Omega\right]-\mathrm{E}[\mathrm{k} \mid \Omega]-\mathrm{re}^{*}(\Omega)-\beta(\Omega) \mathrm{cd}(\Omega)\right] \gamma
$$

where $\beta(\Omega)$ as the equilibrium default risk given the optimal financing choices

$$
\beta(\Omega) \equiv \operatorname{Prob}\left(\mathrm{e}^{*}(\Omega)+\mathrm{d}^{*}(\Omega)+\mathrm{y}_{2}-\mathrm{k}<\mathrm{Q}^{*}(\Omega) \mid \Omega\right) .
$$

The unconditional, ex ante NPV can be written as $\Sigma_{\Omega} \operatorname{EV}(\Omega) \operatorname{Prob}(\Omega)$. Notice within the square bracket of (3), the first term is the expected receipt, the second term is the expected outlay, and the last two terms are the expected costs of equity and debt capital respectively.

Our model highlights a trade-off between debt and equity. Taking on debt frees up the owner's capital for other uses while using equity eliminates the dead-weight loss of bankruptcy. When the trade-off is non-trivial, there exists an endogenous, economic demand for information about future cash flows. ${ }^{11}$ If it appears that $\mathrm{k}$ is likely to be low, the firm may borrow less without violating the operating constraint; if $\mathrm{y}_{2}$ is likely to be low, the firm may switch to equity financing because the debt investor may demand a high repayment $\mathrm{Q} .^{12}$

11 The tradeoff is trivial if equity or debt always dominates as the preferred financing choice. If $\mathrm{r}=$ 0 , equity financing is superior (and free) and is always used. If $\mathrm{c}=0$, debt financing is superior (and free). In either case, any information about $\mathrm{y}_{2}$ or $\mathrm{x}_{2}$ is useless for financing purposes.

12 The way that we model the trade-off (opportunity cost of equity $\mathrm{r}$ vs. bankruptcy cost C) resembles a tax story of debt. In general, the opportunity cost of equity (r) is endogenous in that it depends, among other things, on the leverage of the firm (d) and the tax rate (say $t$ ). An identical economic trade-off appears if we introduce taxes into the model and endogenize the cost of equity $r$ (instead of treating it as exogenous). Since this does not alter the ensuing accounting story nor provide 


\section{Information Environment and the Full Information Benchmark}

\subsection{Properties of the Underlying Information}

Now we focus on the nature of the available information set $\Omega$. The first-period operation generates information about future cash flows. We use two random variables, $\delta$ and $\mu$, to represent the primitive information. ${ }^{13}$ Suppose that $\delta \in \Delta$ contains information about $\mathrm{k}, \mu \in \mathrm{N}$ contains information about $\mathrm{y}_{2}$, and, for tractability, assume that $\delta$ and $\mu$ are independent of each other. In general, $\delta$ and $\mu$ may indicate that future cash flows are likely to be higher or lower than the prior belief. They may simply confirm the prior belief but with higher confidence, or they may not change the prior belief in any respect. To account for these four possibilities, we assume

$$
\delta \in \Delta \equiv\{\mathrm{H}, \mathrm{M}, \mathrm{L}, \varnothing\} \text { and } \mu \in \mathrm{N} \equiv\{\mathrm{H}, \mathrm{M}, \mathrm{L}, \varnothing\}
$$

where the marginal probabilities are $\operatorname{Prob}(\delta=\mathrm{L})=\operatorname{Prob}(\delta=\mathrm{M})=\operatorname{Prob}(\delta=\mathrm{H})=\pi \in(0,1 / 3]$, and $\operatorname{Prob}(\mu=\mathrm{L})=\operatorname{Prob}(\mu=\mathrm{M})=\operatorname{Prob}(\mu=\mathrm{H})=\rho \in(0,1 / 3]$. The joint probability functions are given in the following two tables.

Insert Tables $1 \mathrm{a}$ and $1 \mathrm{~b}$ Here

additional accounting insights, we see no reason to burden the model with more notations and algebra. Further, for a similar reason, we abstract away from an endogenous investment decision, which is an important issue in understanding the effect of information on equilibrium cost of capital (see Kanodia 1980, among others). While our assumptions on the cost of capital and the investment decision are limitations, they allow us to build a richer accounting model to highlight how accounting deals with inherent and incentive uncertainties, which is the main focus of the paper.

13 In addition, realized cash inflow $\mathrm{y}_{1}$ may also contain information about future cash flows $\left(\mathrm{x}_{2}\right.$ and $\mathrm{y}_{2}$ ). We assume information contained in cash flows is a subset (or a garbling) of the information contained in $\delta$ and $\mu$. There is no loss of generality because one can always redefine $\delta$ and $\mu$ such that the assumption is satisfied. 
Intuitively, an $\mathrm{H}(\mathrm{L})$ signal indicates that expected future cash flows are higher (lower) than originally expected. An M signal indicates that new information merely confirms the original expected value with perhaps a change in other cash flow properties (e.g., $\mathrm{k} \mid \delta=\mathrm{M}$ has the same mean but a smaller variance or range compared with the unconditional k). ${ }^{14}$

By assuming $\varnothing \in \Delta$ and $\varnothing \in \mathrm{N}$, we allow $\delta$ and $\mu$ to be null ( $\varnothing)$. When they are null, the conditional distributions are the same as the priors (i.e., $\operatorname{prob}(\mathrm{k} \mid \delta=\varnothing)=\operatorname{prob}(\mathrm{k})$ and $\operatorname{prob}\left(\mathrm{y}_{2} \mid \mu=\varnothing\right)$ $\left.=\operatorname{prob}\left(\mathrm{y}_{2}\right)\right)$. We interpret value $\varnothing$ as representing either no new information or soft information. With no new information, the conditional distributions are, of course, the same as their priors. By soft information, we mean that different parties may disagree on how the information is to be used to update the size and the direction of future cash flows. So, the only agreed-upon distribution of future cash flows is the same as their (common) priors. When the realized $\delta$ and $\mu$ are hard $(\neq \varnothing)$, all parties agree on the updated (conditional) distribution of future cash flows. As a result, ex ante, there exists uncertainty regarding the "hardness" of information variables $\delta$ and $\mu$. For example, if $\pi<1 / 3$, information about $\mathrm{k}$ is hard with probability $3 \pi$ and is soft with probability $1-3 \pi$. We call this the inherent uncertainty regarding the hardness of $\delta$ and $\mu$. When $\pi=1 / 3$, there is no such inherent uncertainty because $\delta$ is always hard. ${ }^{15}$

14 As an alternative device to model information, one can use a state variable and define payoffs as function of the state. Information is then introduced as partitions of the state space. As yet another alternative, one can model primitive signals as future cash flows plus some noise. We suppress the state representation and model information via conditional probabilities. See Christensen and Demski 2003 (chapter 5) for more on the art of modeling information.

15 See Ijiri 1975 for an in-depth discussion on the hardness of information. Intuitively, hard information is objective and leads to an agreement in interpretation. Shipped but uncollected sales are strong evidence for pending cash inflows just as used but unpaid services are evidence of pending cash outflows. In contrast, soft information is subjective and may give rise to disagreements among interested parties, such as the honesty of a loan client or projections of future cash inflows stemming from a new drug discovery. In securities regulation, soft information generally refers to "information about an issuer that inherently involves some subjective analysis or extrapolation, such as projections or estimates" 
Definition 1: We say there is no inherent uncertainty with respect to $\delta(\mu)$ if $\pi=1 / 3(\rho=$ $1 / 3)$ and there is an inherent uncertainty with respect to $\delta(\mu)$ if $\pi<1 / 3(\rho<1 / 3)$

Fundamentally, the hard-vs-soft distinction emphasizes the idea that there must be a minimal level of reliability in $\delta$ and $\mu$ before they are used in a multiple-agent setting. ${ }^{16} \mathrm{Soft}$ information is less useful in a multilateral setting because negotiating (financial) contracts requires a common set of expectations among the interested parties (see e.g., Sunder 1997). If the banker (who wants better credit terms for the bank) or the owner (who wants better terms for the firm) challenges the information presented to them (such as the revenue/expense numbers), there must be some defensible evidence in order to resolve the dispute. Hard information naturally rises to these challenges while soft information does not, by definition. We wish to establish that the presence of this inherent uncertainty significantly influences the design of accrual accounting.

3.2 Full Information Benchmark: $\Omega=\Omega^{\mathrm{FULL}} \equiv\left\langle\mathrm{x}_{1}, \mathrm{y}_{1}, \delta, \mu\right\rangle$

As a benchmark, we consider the ideal setting in which both $\delta$ and $\mu$ are perfectly reproduced by the accounting system on date 1 . That is, $\Omega=\left\langle\mathrm{x}_{1}, \mathrm{y}_{1}, \delta, \mu\right\rangle$. Let $\left\langle\mathrm{e}^{*}(\delta, \mu), \mathrm{d}^{*}(\delta, \mu)\right.$, $\mathrm{Q} *(\delta, \mu)\rangle$ denote the optimal financing choices based on $\langle\delta, \mu\rangle$, suppressing the arguments $\left\langle\mathrm{x}_{1}\right.$, $\left.\mathrm{y}_{1}\right\rangle$. Solving the financing problem under full information yields the following:

Lemma 1: Assume $0<Y_{L}<X, c / 3<r<2 c / 3$, under full information, the optimal financing arrangement is

Table 2

(Jennings et al. 1998, p. 231).

16 With a single-person decision setting, this distinction is less important because the decision maker would choose to put appropriate weights on both hard and soft information in his possession to best maximize his/her objective function. 


\begin{tabular}{|c|c|c|c|c|}
\hline \multirow{2}{*}{\multicolumn{2}{|c|}{$\begin{array}{l}\text { Revenue information: } \mu \\
\text { (probability) }\end{array}$}} & \multicolumn{3}{|c|}{ Expense information: $\delta$ (probability) } \\
\hline & & $\varnothing$ or $\mathrm{H}(1-2 \pi)$ & $\mathrm{M}(\pi)$ & $\mathrm{L}(\pi)$ \\
\hline \multicolumn{2}{|c|}{$H(\rho)$} & $\begin{array}{l}\mathrm{d}=\mathrm{X} \\
\mathrm{e}=0\end{array}$ & $\begin{array}{l}\mathrm{d}=2 \mathrm{X} / 3 \\
\mathrm{e}=0\end{array}$ & $\begin{array}{l}d=X / 3 \\
e=0\end{array}$ \\
\hline \multirow{2}{*}{$\begin{array}{l}\varnothing \text { or } M \\
(1-2 \rho)\end{array}$} & $\mathrm{c} / 2<\mathrm{r}$ & $\begin{array}{l}d=X \\
e=0\end{array}$ & $\begin{array}{l}d=2 X / 3 \\
e=0\end{array}$ & $\begin{array}{l}\mathrm{d}=\mathrm{X} / 3 \\
\mathrm{e}=0\end{array}$ \\
\hline & $\mathrm{r}<\mathrm{c} / 2$ & $\begin{array}{l}d=Y_{L} \\
e=X-Y_{L}\end{array}$ & $\begin{array}{l}\mathrm{d}=\min \left(\mathrm{Y}_{\mathrm{L}}, 2 \mathrm{X} / 3\right) \\
\mathrm{e}=2 \mathrm{X} / 3-\mathrm{d}\end{array}$ & $\begin{array}{l}\mathrm{d}=\min \left(\mathrm{Y}_{\mathrm{L}}, \mathrm{X} / 3\right) \\
\mathrm{e}=\mathrm{X} / 3-\mathrm{d}\end{array}$ \\
\hline \multicolumn{2}{|c|}{$\mathrm{L}(\rho)$} & $\begin{array}{l}d=Y_{L} \\
e=X-Y_{I}\end{array}$ & $\begin{array}{l}\mathrm{d}=\min \left(\mathrm{Y}_{\mathrm{L}}, 2 \mathrm{X} / 3\right) \\
\mathrm{e}=2 \mathrm{X} / 3-\mathrm{d}\end{array}$ & $\begin{array}{l}\mathrm{d}=\min \left(\mathrm{Y}_{\mathrm{L}}, \mathrm{X} / 3\right) \\
\mathrm{e}=\mathrm{X} / 3-\mathrm{d}\end{array}$ \\
\hline
\end{tabular}

(All proofs are placed in the appendix)

Intuitively, if the future cash inflow $\left(\mathrm{y}_{2}\right)$ is likely to be high $(\mu=\mathrm{H})$, the default risk is low; optimal $\mathrm{d}($.$) is chosen according to the maximum cash outflow (k), which is based on$ information provided by $\delta$. If the future cash inflow is likely to be low $(\mu=\mathrm{L})$, the default risk is high; optimal $\mathrm{d}($.$) is chosen to avoid default (i.e., \mathrm{Y}_{\mathrm{L}}$ or the highest $\mathrm{k}$ given $\delta$, whichever is lower) with the rest of the funding provided by equity. In cases which fall in-between (i.e., $\mu=$ M or $\varnothing$ ), financing choices are made by a similar cost-benefit analysis.

In this benchmark case, the firm achieves economic efficiency because all available information is assumed to be perfectly known to the decision makers. However, in practice, such ideal conditions are not commonly met. So, we assume these primitive signals ( $\delta$ and $\mu$ ) are not observable by equity and debt investors. Instead, an accounting system transforms the signals into accounting numbers, which are reported to investors for making their financing decisions.

In the following sections, we explore desirable accounting properties in a sequence of three environments: (1) with a lack of inherent uncertainties, (2) with inherent but not incentive 
uncertainties, (3) with both inherent and incentive uncertainties. Our intent is to explore how accruals should be constructed in response to different informational and behavioral environments.

\section{Lack of Inherent Uncertainties and Fair Value Accounting}

\subsection{Cash Accounting and Fair Value Accounting}

Let $F$ represent all non-cash elements in $\Omega$, so $\Omega=\left\langle y_{1}, x_{1}, F\right\rangle$. Consider $F$ a mapping from the underlying raw information (i.e., $\mathrm{x}_{1}, \mathrm{y}_{1}, \delta, \mu$ ) to accounting items, such as revenues and expenses. A simple example is Cash Accounting, denoted $\mathrm{F}^{\mathrm{CASH}}=\langle\mathrm{rev}$, exp $\rangle$, where

$$
\mathrm{F}^{\mathrm{CASH}}\left(\mathrm{x}_{1}, \mathrm{y}_{1}, \delta, \mu\right)=\langle\text { rev, } \exp \rangle=\left\langle\mathrm{y}_{1}, \mathrm{x}_{1}\right\rangle
$$

The date- 1 information set under cash accounting is $\Omega=\Omega^{\mathrm{CASH}} \equiv\left\langle\mathrm{x}_{1}, \mathrm{y}_{1}, \mathrm{~F}^{\mathrm{CASH}}\right\rangle$. Cash accounting ignores any non-cash elements in the raw information set and prevents accounting from revealing anything about $\delta$ and $\mu$ to users, except for the unlikely case where realized cash flows already convey all the information contained in $\delta$ and $\mu$.

In contrast, non-trivial accrual accounting allows revenues and/or expenses to be different from cash inflows/outflows, with the differences booked as cost/revenue deferrals or accruals. These deferrals/accruals have the potential to convey more information about future cash flows, which may improve firm decision making. Consider another natural benchmark accounting policy where earnings correspond to economic income. Revenues (or expenses) are recognized as the realized cash inflows (or outflows) plus the expected value of the future cash inflows (or outflows). Since these accounting numbers are unbiased estimates of total cash flows, we call this Fair Value Accounting, denoted $\mathrm{F}^{\mathrm{FV}}=\langle\mathrm{rev}$, exp $\rangle$, where

$$
\mathrm{rev}=\mathrm{y}_{1}+\mathrm{E}\left[\mathrm{y}_{2} \mid \mu\right], \text { and } \exp =\mathrm{x}_{1}+\mathrm{E}\left[\mathrm{x}_{2} \mid \delta\right]
$$


Under fair value accounting the date- 1 information set is $\Omega=\Omega^{\mathrm{FV}} \equiv\left\langle\mathrm{x}_{1}, \mathrm{y}_{1}, \mathrm{~F}^{\mathrm{FV}}\right\rangle$. Note that the fair value measures represent value-in-use. They correspond to Level 3 estimates using the Income Approach specified in the recent FASB exposure draft on fair value. ${ }^{17}$

From an income-measurement perspective, fair value accounting recognizes both cash and non-cash revenues and expenses. From an information perspective, fair value accounting allows the firm to release information, over and above the realized cash flows, through accruals. In particular, $\mathrm{F}($.$) and realized cash flows combine to reveal accruals (e.g., rev -\mathrm{y}_{1}=\mathrm{E}\left[\mathrm{y}_{2} \mid \mu\right]$ ), which in turn, tell the users something, though perhaps not everything, about the underlying $\delta$ and $\mu$. See Table 3 for the mapping from $\delta$ and $\mu$ to revenues and expenses under fair value as well as cash accounting.

Insert Table 3 Here

\subsection{Optimal Economic Decisions under Fair Value Accounting}

When there are no inherent uncertainties, the expected future cash flow conveys all the necessary information needed for optimal financing choices. As a result, fair value accounting has the desirable property of inducing optimal financing decisions. ${ }^{18}$

Proposition 1: Assume no inherent uncertainties with respect to $\delta$ or $\mu$ (i.e., $\rho=\pi=1 / 3$ ) (1) Under fair value accounting, revenues and expenses are invertible in $\langle\delta, \mu\rangle$; and

17 See pages 3-9 of exposure draft "Fair Value Measurements" issued by the Financial Accounting Standards Board on June 23, 2004.

18 Under a generic accounting policy $\mathrm{F}\left(\right.$.), the date- 1 information set is $\Omega=\left\langle\mathrm{x}_{1}, \mathrm{y}_{1}, \mathrm{~F}().\right\rangle$ and the optimal financing choices are denoted $\mathrm{e}^{*}(\Omega), \mathrm{d}^{*}(\Omega)$, and $\mathrm{Q}^{*}(\Omega)$. To highlight additional information contained in accruals and to unclog notations, we suppress arguments $\mathrm{x}_{1}$ and $\mathrm{y}_{1}$ in $\mathrm{F}(),. \mathrm{e}^{*}(),. \mathrm{d}^{*}($.$) , and$ $\mathrm{Q}^{*}($.$) ; and we write \mathrm{F}(\delta, \mu), \mathrm{e}^{*}(\mathrm{~F}(\delta, \mu)), \mathrm{d}^{*}(\mathrm{~F}(\delta, \mu))$, and $\mathrm{Q}^{*}(\mathrm{~F}(\delta, \mu))$ throughout the paper. 
(2) Fair value accounting induces optimal financing decisions. That is, for all $\delta \in \Delta$ and $\mu \in \mathrm{N}$ :

$\mathrm{e}^{*}\left(\mathrm{~F}^{\mathrm{FV}}(\delta, \mu)\right)=\mathrm{e}^{*}(\delta, \mu) ; \mathrm{d}^{*}\left(\mathrm{~F}^{\mathrm{FV}}(\delta, \mu)\right)=\mathrm{d}^{*}(\delta, \mu) ; \mathrm{Q}^{*}\left(\mathrm{~F}^{\mathrm{FV}}(\delta, \mu)\right)=\mathrm{Q}^{*}(\delta, \mu)$.

(3) If realized cash flow $y_{1}$ does not perfectly reveal $\delta$ or $\mu$, then fair value accounting is strictly preferred to cash accounting, or

$$
\sum_{\delta \mu} \operatorname{EV}\left(\Omega^{\mathrm{CASH}}\right) \operatorname{Prob}(\delta, \mu)<\sum_{\delta \mu} \mathrm{EV}\left(\Omega^{\mathrm{FV}}\right) \operatorname{Prob}(\delta, \mu) .
$$

Intuitively, when there are no inherent uncertainties, information is always hard and, in our model, there exists a one-to-one mapping between $\mathrm{E}\left[\mathrm{x}_{2} \mid \delta\right]$ and $\delta$ and, similarly, between $\mathrm{E}\left[\mathrm{y}_{2} \mid \mu\right]$ and $\mu$. Knowing the accruals is identical to knowing the underlying $\delta$ and $\mu$. See Table 3a for optimal capital structure choices under the fair value accounting with no inherent uncertainty.

Insert Table 3a Here

However, if there exist inherent uncertainties, the fair value accounting does not fully reflect the resolution of these uncertainties. To illustrate, suppose there is an inherent uncertainty with $\delta(\pi<1 / 3)$. The expectation of $\mathrm{x}_{2}$ is the same when $\delta$ is average $(\mathrm{M})$ as when $\delta$ is null $(\varnothing)$. That is: $\mathrm{E}\left[\mathrm{x}_{2} \mid \delta=\mathrm{M}\right]=\mathrm{E}\left[\mathrm{x}_{2} \mid \delta=\varnothing\right]$. The fair value accrual does not distinguish the state where $\delta$ is average (M) from the state where $\delta$ is null ( $\varnothing)$. These two different states imply different properties of the future cash outflow (k): $\delta=\mathrm{M}$ signals a lower variance of the future cash outflow k. The lowered variance may lower the default risk if the firm chooses debtfinancing. Distinguishing $\delta=M$ from $\delta=\varnothing$ can be crucial in making financing choices. However, the fair value policy does not make such a distinction, which leads to sub-optimal decisions (see 
Table $3 \mathrm{~b}$ for financing choices under fair value accounting with inherent uncertainties). This is a weakness of conveying information using point estimates. We use Graph 1 to illustrate this example.

Graph 1: Expenses under the Fair Value Policy

\begin{tabular}{|c|c|c|c|c|}
\hline $\begin{array}{c}\text { Underlying } \\
\text { Information } \\
\delta\end{array}$ & & $\begin{array}{l}\text { Effect on } \\
\text { Default Risk }\end{array}$ & & $\begin{array}{l}\text { Reported } \\
\text { Expense } \\
\text { Accrual }\end{array}$ \\
\hline $\operatorname{good}(\mathrm{L})$ & $\rightarrow$ & decreased & $\rightarrow$ & $\mathrm{E}\left[\mathrm{x}_{2} \mid \delta=\mathrm{H}\right]$ \\
\hline confirming (M) & $\rightarrow$ & decreased & $\rightarrow$ & $E\left[x_{2}\right]$ \\
\hline $\operatorname{bad}(\mathrm{H})$ & $\rightarrow$ & increased & $\rightarrow$ & $\mathrm{E}\left[\mathrm{x}_{2} \mid \delta=\mathrm{L}\right]$ \\
\hline null or soft (Ø) & $\rightarrow$ & same as prior & $\rightarrow$ & $E\left[x_{2}\right]$ \\
\hline
\end{tabular}

Insert Table $3 b$ Here

\section{Inherent Uncertainties and Flexible Accounting}

\subsection{Flexible Accounting}

Now we introduce a flexible accounting policy where the recognition of

revenues/expenses depends not only on the mean of future cash flows but also on the hardness of the information. If the underlying signals are absent or soft $($ e.g., $\delta=\varnothing)$, no accruals are booked even though the expected future cash flow is not zero. Consider the following specification of Flexible Accounting, denoted $\mathrm{F}^{\mathrm{FLEX}}=\langle\mathrm{rev}$, exp $\rangle$, 


$$
\mathrm{F}^{\mathrm{FLEX}}(\operatorname{rev}, \exp )=\left\{\begin{array}{cc}
\left(\mathrm{y}_{1}+\mathrm{E}\left[\mathrm{y}_{2} \mid \mu\right], \mathrm{x}_{1}+\mathrm{E}\left[\mathrm{x}_{2} \mid \delta\right]\right) & \text { if } \mu \neq \varnothing \text { and } \delta \neq \varnothing \\
\left(\left(\mathrm{y}_{1}+\mathrm{E}\left[\mathrm{y}_{2} \mid \mu\right) \frac{\mathrm{x}_{1}}{\mathrm{x}_{1}+\mathrm{E}\left[\mathrm{x}_{2}\right]}, \mathrm{x}_{1}\right)\right. & \text { if } \mu \neq \varnothing \text { and } \delta=\varnothing \\
\left(\mathrm{y}_{1},\left(\mathrm{x}_{1}+\mathrm{E}\left[\mathrm{x}_{2} \mid \delta\right]\right) \frac{\mathrm{y}_{1}}{\mathrm{y}_{1}+\mathrm{E}\left[\mathrm{y}_{2}\right]}\right) & \text { if } \mu=\varnothing \text { and } \delta \neq \varnothing \\
(0,0) & \text { if } \mu=\varnothing \text { and } \delta=\varnothing
\end{array}\right.
$$

The date- 1 information set under flexible accounting is: $\Omega=\Omega^{\mathrm{FLEX}} \equiv\left\langle\mathrm{x}_{1}, \mathrm{y}_{1}, \mathrm{~F}^{\mathrm{FLEX}}\right\rangle .{ }^{19}$ See Table 4 for the mapping from $\delta$ and $\mu$ to revenues and expenses under this policy.

Insert Table 4 Here

Under the flexible accounting, the amount of revenue recognized is limited by the softness of the underlying information. The flexible accounting resembles the current GAAP in that uncertainties with respect to both resource inflows as well as outflows determine revenue recognition: revenues must be both "realized or realizable" and "earned" in order to be recognized. ${ }^{20}$ In the first case where $\mu \neq \varnothing$ and $\delta \neq \varnothing$, hard information is available for both cash

19 Notice, a matching rule is followed. That is: for all rev, $\exp =\left(\mathrm{x}_{1}+\mathrm{E}\left[\mathrm{x}_{2} \mid \delta\right]\right) \frac{\mathrm{rev}}{\mathrm{y}_{1}+\mathrm{E}\left[\mathrm{y}_{2} \mid \mu\right]}$.

The same results are obtained if the matching requirement is dropped and the Flexible Accounting can be alternatively defined as:

$\mathrm{F}^{\mathrm{FLEX}}(\operatorname{rev}, \exp )=\left\{\begin{array}{cc}\left(\mathrm{y}_{1}+\mathrm{E}\left[\mathrm{y}_{2} \mid \mu\right], \mathrm{x}_{1}+\mathrm{E}\left[\mathrm{x}_{2} \mid \delta\right]\right) & \text { if } \mu \neq \varnothing \text { and } \delta \neq \varnothing \\ \left(\mathrm{y}_{1}+\mathrm{E}\left[\mathrm{y}_{2} \mid \mu\right], \mathrm{x}_{1}\right) & \text { if } \mu \neq \varnothing \text { and } \delta=\varnothing \\ \left(\mathrm{y}_{1}, \mathrm{x}_{1}+\mathrm{E}\left[\mathrm{x}_{2} \mid \delta\right]\right) & \text { if } \mu=\varnothing \text { and } \delta \neq \varnothing \\ \left(\mathrm{y}_{1}, \mathrm{x}_{1}\right) & \text { if } \mu=\varnothing \text { and } \delta=\varnothing\end{array}\right.$

$20 \quad$ See FASB conceptual statement No. 5, paragraph 83. 
inflows and outflows. This is the case, for instance, when cash flow $\mathrm{y}_{1}$ is "realized", and $\mathrm{E}\left[\mathrm{y}_{2} \mid \mu\right]$ is "realizable" based on hard information $(\mu \neq \varnothing)$. In addition, even though only the $\mathrm{x}_{1}$ portion has been paid, the total costs $\left(\mathrm{x}_{1}+\mathrm{E}\left[\mathrm{x}_{2} \mid \delta\right]\right)$ are "incurred" upon the arrival of the hard expense information $(\delta \neq \varnothing)$. Since the total costs are incurred, all revenues $\left(\mathrm{y}_{1}+\mathrm{E}\left[\mathrm{y}_{2} \mid \mu\right]\right)$ are considered "earned." Therefore, under the current GAAP, recognized revenues are equal to $\left(\mathrm{y}_{1}+\mathrm{E}\left[\mathrm{y}_{2} \mid \mu\right]\right)$.

In the second case, hard information is available about $\mathrm{y}_{2}$ but not about $\mathrm{x}_{2}$. As a result, even though both $\mathrm{y}_{1}$ and $\mathrm{y}_{2}$ are either "realized or realizable", a high degree of uncertainty remains regarding how much has been "earned" due to the uncertainty about the total costs $(\delta=$ $\varnothing$ ). One example would be an airline issuing free frequent flyer miles when tickets are sold. In this case, all inflows are realized. However, a high degree of uncertainty remains regarding the cost the airline will incur fulfilling the frequent flyer miles obligation. So the current GAAP requires that the total cash receipts be allocated between recognized revenues and unearned revenues, based on the cost incurred and the projected future cost to be incurred. ${ }^{21}$ In other words, revenue equals $\left(\mathrm{y}_{1}+\mathrm{E}\left[\mathrm{y}_{2} \mid \mu\right]\right) \frac{\mathrm{x}_{1}}{\mathrm{x}_{1}+\mathrm{E}\left[\mathrm{x}_{2}\right]}$. Note that in this case the recognized revenue is "realized or realizable" since the total revenue $\left(\mathrm{y}_{1}+\mathrm{E}\left[\mathrm{y}_{2}\right]\right)$ is "realized and realizable" $(\mu \neq \varnothing)$. More importantly, because future costs are subjected to high uncertainty $(\delta=\varnothing)$, only the $\mathrm{x}_{1}$ portion is certain and, thus, considered "incurred." As a result, only a portion of total revenues that matches the expenses $x_{1}$ satisfies the "earned" condition. The total amount of recognized revenue, therefore, should be $\left(\mathrm{y}_{1}+\mathrm{E}\left[\mathrm{y}_{2} \mid \mu\right]\right) \frac{\mathrm{x}_{1}}{\mathrm{x}_{1}+\mathrm{E}\left[\mathrm{x}_{2}\right]} \cdot{ }^{22}$

$21 \quad$ SEC Staff Accounting Bulletin No. 101, December $3^{\text {rd }}, 1999$.

22 Anther example of the above accounting practice is the "percentage-of-completion" method of accounting for long-term contracts. In a situation in which the total costs of completing the project are uncertain while the total cash receipts are relatively more certain, revenues are recognized based on the portion of costs incurred relative to the total projected costs, i.e., $\mathrm{x}_{1} /\left(\mathrm{x}_{1}+\mathrm{E}\left[\mathrm{x}_{2}\right]\right)$. See "Accounting for 
In the third case, hard information is available on $\mathrm{x}_{2}$ but not on $\mathrm{y}_{2}$. This corresponds to the case in which total expenses are more certain, but significant uncertainty remains with respect to total revenues. A typical case would be the accounting for natural resources (e.g., accounting for oil reserve by companies, such as Royal Dutch/Shell Group). Since a considerable level of uncertainty exists with respect to the total eventual output, only the "realized" portion $\left(\mathrm{y}_{1}\right)$ is certain enough to meet the "realized or realizable" condition. Thus the revenues recognized equals $\mathrm{y}_{1}$, and expenses are matched accordingly. The unrecognized expenses (even though incurred) are deferred. These costs are recognized as assets and then amortized or depreciated over time. Note that in this case, $\mathrm{y}_{1}$ also satisfies the "earned" condition because of less uncertainty with total expenses, $\mathrm{x}_{1}+\mathrm{E}\left[\mathrm{x}_{2} \mid \delta\right]$.

In the fourth case, considerable uncertainty remains with respect to both $\mathrm{y}_{2}$ and $\mathrm{x}_{2}$. In this case even though cash realized $\left(\mathrm{y}_{1}\right)$ is certain, it is not clear how much has been "earned" due to the uncertainty of the total cash outflow needed $(\delta=\varnothing)$. Hence the revenue recognized equals 0 because part of $\mathrm{y}_{1}$ might have not been "earned". This is the "completed contract" method in accounting for long-term contracts. ${ }^{23}$ When a high degree of uncertainty exists about both cash inflow and cash outflows of this contract, GAAP requires no revenue or expense be recognized until the contract is completed and all uncertainties are resolved.

The key to flexible accounting is that both the uncertainty level about the cash inflow and the uncertainty level about the cash outflow affect the recognition of revenues. That is, as the

Performance of Construction-Type and Certain production-Type Contracts," Statement of Position 81-1 (New York: AICPA, 1981).

23 See AICPA "Accounting for Performance of Construction-Type and Certain production-Type Contracts," Statement of Position 81-1 (New York: AICPA, 1981). 
GAAP states, revenues must be both "realized or realizable" as well as "earned". Because of this, no single accounting method (fair value or historical cost) applies uniformly. It is understood between the users and the preparers of financial statements that different rules are applied under different circumstances.

From an information perspective, flexible accounting addresses, and perhaps overcomes, the weakness of the fair value approach because the recognition rules take into account the inherent uncertainties associated with future cash flows. The choice among permissible recognition rules itself conveys information. In particular, the non-recognition of future inflow (outflow) signals a higher remaining uncertainty. In the financing decision context, this feature of flexible accounting is critical because it enables users to distinguish between important states and therefore improve their financing decisions.

\subsection{Optimal Economic Decisions under Flexible Accounting}

Given the amount of information the flexible accounting policy conveys and given the absence of any opportunistic (ab)use, it is not surprising that flexible accounting is weakly preferable to fair value accounting (since more information may simply be disregarded if not deemed useful). Proposition 1 establishes a strict preference for flexible accounting given our financing setting (see Table 4a for optimal capital structure choices under flexible accounting with inherent uncertainty).

Insert Table 4a Here

Proposition 2: Assume $\operatorname{Prob}(\delta=\varnothing) \neq 0$ and $\operatorname{Prob}(\mu=\varnothing) \neq 0$, i.e., inherent uncertainties exist regarding $\delta$ and $\mu$. 
(1) Under flexible accounting, revenue and expense are invertible in $\langle\delta, \mu\rangle$;

(2) Flexible accounting induces optimal financing decision. That is, for all $\delta \in \Delta$ and $\mu \in \mathrm{N}$ :

$\mathrm{e}^{*}\left(\mathrm{~F}^{\mathrm{FLEX}}(\delta, \mu)\right)=\mathrm{e}^{*}(\delta, \mu) ; \mathrm{d}^{*}\left(\mathrm{~F}^{\mathrm{FLEX}}(\delta, \mu)\right)=\mathrm{d}^{*}(\delta, \mu) ; \mathrm{Q}^{*}\left(\mathrm{~F}^{\mathrm{FLEX}}(\delta, \mu)\right)=\mathrm{Q} *(\delta, \mu)$.

(3) If realized cash flow $y_{1}$ does not perfectly distinguish $\delta=\mathrm{M}$ and $\delta=\varnothing$ and $\sup (\mathrm{k} \mid \delta=\mathrm{M})<\mathrm{Y}_{\mathrm{L}}<\sup (\mathrm{k})<\mathrm{Y}_{\mathrm{H}}$, then flexible accounting is strictly preferred to fair value accounting, or:

$$
\sum_{\delta \mu} \operatorname{EV}\left(\Omega^{\mathrm{FV}}\right) \operatorname{Prob}(\delta, \mu)<\sum_{\delta \mu} \operatorname{EV}\left(\Omega^{\mathrm{FLEX}}\right) \operatorname{Prob}(\delta, \mu) .
$$

Compared with the fair value accounting, flexible accounting is better at handling the inherent uncertainties in $\delta$ and $\mu$. The fair value accounting forces a pooling of hard (M) and soft signals $(\varnothing)$ while flexible accounting distinguishes them via a recognition apparatus (by the non-recognition of soft information). Hence, in this model, flexible accounting can fully restore optimal financing choices, which makes it weakly preferable. To illustrate a strict preference, we consider a setting where $\delta=\mathrm{M}$ and $\delta=\varnothing$ induce different financing choices. Given $\sup (\mathrm{k} \mid \delta=$ $\mathrm{M})<\mathrm{Y}_{\mathrm{L}}<\sup (\mathrm{k})<\mathrm{Y}_{\mathrm{H}}$, the default risk is zero and the funding need is $2 \mathrm{X} / 3$ when $\delta=\mathrm{M}$, while the default risk is non-zero and the funding need is $\mathrm{X}$ when $\delta=\varnothing$. The flexible accounting policy, with its ability to distinguish between $\delta=M$ and $\delta=\varnothing$, allows for a fine-tuning of the debt or equity choices. The key feature of flexible accounting is its ability to convey higher moments (of the random variable $\delta$ ), such as range or variance, not just the means, through the judicious use of revenue recognition rules. ${ }^{24}$ We would like to point out that our result critically depends

24 The flexible accounting policy we choose to emphasize in this paper is not the only one that can overcome the weakness of the fair value policy. Technically, an infinite number of recognition policies (including unconventional ones such as using different smiling faces as an indicator, as some have suggested) will work as long as the message's dimensionality is large enough. So, the suitable policy is not unique. However, we see, in practice, recognition polices similar to the one we consider. According to standard-setters, recognition issues revolve around the so-called reliability/relevance trade-off. They claim that such trade-offs may require the accountant to choose from among alternative recognition policies, which include (1) non-recognition, (2) use of conventions, and (3) use of estimates and 
on the presence of inherent uncertainty. If no "hard" realizations of $\delta(\mathrm{H}, \mathrm{M}$, or $\mathrm{L})$ induce the same expectation of $\mathrm{k}$ as the "soft" realization $(\varnothing)$, fair value approach would produce desirable capital choices.

\section{Stringent Accounting in Environments with Inherent and Incentive Uncertainties}

So far we have assumed the accounting process is perfect and without any intentional abuses. In this section we introduce managerial incentives and examine how they affect the design of accounting policies. Managerial incentives may lead to conflicts of interest. Common examples include owner-manager conflict, equityholder-debtholder conflict, and accountantmanager conflict. Such conflicts of interest invite opportunistic (ab)use of accounting policies. Given that such incentives exist, additional uncertainty is introduced into the accounting numbers when users try to make inferences based on reported numbers. We call this additional uncertainty incentive uncertainty. In this section, we probe this question by considering a potential conflict between the manager/owner and the banker.

\subsection{Incentive Uncertainty}

In our model, suppose a manager privately observes $\delta$ and $\mu$ before they enter accounting process and into firm financial statements. If the manager acts on the owner's behalf, he may favor the owner by being selective in his submission decisions. To illustrate, in cases of $\mu=\mathrm{H}$, the manager has an incentive to submit $\mu=\mathrm{H}$ to book a favorable revenue accrual so that better

approximations. In choosing from among these alternatives, they warned accountants to use "care and attention to the circumstances at hand. Otherwise, their application may result in a reduction in the reliability (and sometimes the relevance) of financial statement information. Accountants must be continually mindful of whether what is gained by using those alternatives more than offsets what may be lost by their application (See Johnson and Storey 1982 p. 8)." In this paper, we provide a framework where the reliability concerns arise from inherent as well incentive uncertainties, and (in response) accounting instruments include, indeed, the use of non-recognition and conventions. 
credit terms (a lower Q) may be obtained. In cases of $\mu=\mathrm{L}$, he has an incentive to withhold the information by simply stating that there is no new information (claiming $\mu=\varnothing$ ), which is intended to avoid a higher Q. Given the private nature the $\mu$-information, the accounting process cannot distinguish between the lack of new information $(\mu=\varnothing)$ and the withholding of unfavorable information $(\mu=\mathrm{L}){ }^{25}$ As a result, the manager has both the incentive and the ability to misrepresent his private information. ${ }^{26}$ Graph 2 illustrates incentive uncertainty in our setting.

Definition 2: We say there is incentive uncertainty if

(i) there exist inherent uncertainties with respect to $\delta$ and $\mu$;

(ii) $\delta$ and $\mu$ are privately observed by the manager; and

(iii) the manager cannot credibly convey $\delta=\varnothing$ or $\mu=\varnothing$.

Graph 2: Information Flows under Incentive Uncertainty

\begin{tabular}{|c|c|c|c|c|c|c|}
\hline $\begin{array}{l}\text { Underlying } \\
\text { Information } \mu\end{array}$ & & $\begin{array}{l}\text { Expected } \\
\text { Value of } y_{2}\end{array}$ & & $\begin{array}{c}\text { Effect on } \\
\text { Default Risk }\end{array}$ & & $\begin{array}{c}\text { Opportunistic } \\
\text { Accruals }\end{array}$ \\
\hline $\operatorname{good}(\mathrm{H})$ & \multirow{2}{*}{$\begin{array}{l}\rightarrow \\
\rightarrow\end{array}$} & high & $\rightarrow$ & decreased & $\rightarrow$ & $\begin{array}{l}\text { rev }=y_{1}+ \\
\mathrm{E}\left[\mathrm{y}_{2} \mid \mu=\mathrm{H}\right]\end{array}$ \\
\hline $\begin{array}{l}\text { confirming } \\
\text { (M) }\end{array}$ & & same as prior & $\rightarrow$ & unchanged & $\rightarrow$ & $\begin{array}{c}\mathrm{rev}=\mathrm{y}_{1}+ \\
\mathrm{E}\left[\mathrm{y}_{2}\right]\end{array}$ \\
\hline $\operatorname{bad}(L)$ & \multirow[t]{2}{*}{$\rightarrow$} & low & $->$ & increased & \multirow{2}{*}{$\rightarrow$} & \multirow{2}{*}{$r e v=y_{1}$} \\
\hline null or soft (ø) & & same as prior & $\rightarrow$ & same as prior & & \\
\hline
\end{tabular}

25 Similar assumptions are made in the disclosure literature (e.g., Dye 1985). In legal terms, there is a distinction between positive vs. negative evidence. Here reported realizations of $\mu(\mathrm{H}$ and $\mathrm{M})$ are positive evidence. No disclosure is negative evidence which implies that $\mu$ is either $\varnothing$ or L. As usual, negative evidence is not as discriminating.

26 The changes to Accounting Information in Figure 1 (page 10) are illustrated below:

Operating Cash Flows

Financing Cash Flows

Accounting Information $+\mathrm{y}_{1}$

manager privately

observes $\delta$ and $\mu$

submits $\delta$ ' and $\mu$ '
$\mathrm{F}\left(\delta^{\prime}, \mu^{\prime}\right)$

reported $-\mathrm{x}_{2}$

$$
+\mathrm{e},+\mathrm{d}
$$


When rev $=y_{1}$ is reported, which is purported to convey " $\mu=\varnothing "$, a rational, competitive banker would, in response, insist on a modified credit term, such as a weighted average of the two states: $\mu=\varnothing$ or $\mu=\mathrm{L}$. This would benefit the owner when $\mu$ is truly low but hurt the owner when in fact $\mu=\varnothing$. Anticipating such interactions, the firm may be better off without such private information in some cases. In turn, a contract that commits the manager not to abuse his power may be desirable. However, any such contract between the manager and the banker can be difficult to enforce because the ex post detection of withheld information is problematic. (See Table $4 \mathrm{~b}$ for optimal capital structure choices under flexible accounting with incentive uncertainty.)

Insert Table $4 \mathrm{~b}$ Here

\subsection{Stringent Accounting Policy as a Commitment}

Alternatively, accounting policy can be made more restrictive. Consider a cash-based revenue recognition rule: Stringent Accounting, denoted $\mathrm{F}^{\mathrm{S}}=\langle\mathrm{rev}$, exp $\rangle$, where

$$
\mathrm{rev}=\mathrm{y}_{1} \text {, and } \exp =\left(\mathrm{x}_{1}+\mathrm{E}\left[\mathrm{x}_{2} \mid \delta\right]\right) \frac{\mathrm{y}_{1}}{\mathrm{y}_{1}+\mathrm{E}\left[\mathrm{y}_{2}\right]}
$$

Under stringent accounting the date-1 information set under is: $\Omega=\Omega^{\mathrm{S}} \equiv\left\langle\mathrm{x}_{1}, \mathrm{y}_{1}, \mathrm{~F}^{\mathrm{S}}\right\rangle$. (See Table 5 for the mapping from $\delta$ and $\mu$ to revenues and expenses under stringent accounting.) Under such a regime, no revenue accruals are booked while information about future cash outflow $(\delta)$ is partially conveyed. We show that, under some conditions, the firm may find it optimal to credibly commit not to abuse $\mu$ information by agreeing to such a stringent accounting policy. 
(See Table 5a for optimal capital structure choices under stringent accounting with both inherent and incentive uncertainties.)

Insert Tables 5 and $5 \mathrm{a}$ Here

Proposition 3: Assume the presence of both inherent and incentive uncertainties. Suppose the realized cash inflow $\mathrm{y}_{1}$ is not informative about future cash flows. If $\rho$ is sufficiently low, then there exists a set of parameters $\langle\mathrm{r}, \mathrm{c}\rangle$ with positive measures where stringent accounting is strictly preferred to flexible accounting, or,

$$
\sum_{\delta \mu} \operatorname{EV}\left(\Omega^{\mathrm{FLEX}}\right) \operatorname{Prob}(\delta, \mu)<\sum_{\delta \mu} \operatorname{EV}\left(\Omega^{\mathrm{S}}\right) \operatorname{Prob}(\delta, \mu) .
$$

Intuitively, the manager has an incentive to withhold unfavorable default risk information $(\mu=\mathrm{L})$. However, a low enough $\rho$ implies that the ex ante benefit of such opportunistic behavior is low, while the loss when $\mu=\varnothing$ is high (and occurs with probability 1-3p). Overall, the economic loss due to information asymmetry is large. By agreeing to the stringent accounting policy, unfavorable credit terms are avoided. At the same time, the firm may lose the favorable credit terms when $\mu$ is truly high. When the cost avoided exceeds the benefit lost, it is optimal to commit to a stringent accounting policy. As a result, incentive concerns reduce flexibility in the accounting standards. ${ }^{27}$

\subsection{Discussion}

$27 \quad$ The idea that an ex ante efficiency arrangement involves some ex post inefficiency also appears in Baiman 1975, Truman and Titman 1988, and Arya, Glover, and Sunder 1998 where parties agree to commit not to discover some information. A slightly variant argument is at work here. Ex ante efficiency is achieved by committing to only use a subset of information (as opposed to all possible information). Pacharn 2003 uses a similar argument in explaining why certain accounting methods (e.g., depreciation) only use a subset of information (typical depreciation expenses ignore some relevant market values). More generally, any piece of information may be better left out of the accounting report when the interpretation of its "bad" signals is subjected to a more severe asymmetric information problem than the interpretation of its "good" signals. 
The incentive consideration enhances the argument for a stricter reliability requirement for revenue recognition. Without incentive issues, the non-recognition of soft information arises from a desire to facilitate finer financing transactions. With an incentive issue present, the reliability concern (due to information asymmetry) gives rise to a non-recognition of both hard and soft information. More importantly, such a reliability requirement is in the best interest of the firm. That is, while the owner/manager in certain situations may, ex post, benefit from loose recognition requirements (e.g., high realizations of $\mu$ ), he may, ex ante, be better-off with a strict recognition rule given the anticipated unfavorable response from other economic parties (e.g., the banker). As we pointed out earlier, this is in contrast to Dye and Verrecchia 1995, who show that a flexible GAAP is preferred to a stringent GAAP in the presence of internal managerial incentives. A fully committed managerial contract, which is absent in our setting, can exploit the flexible GAAP to better control a self-interested manager.

The result also has implications regarding the information environment and accounting. For example, a major portion of the assets of high tech firms are intangibles. The value of these assets arguably depends more on soft information. In this case, our results indicate that allowing firms to recognize some of the assets may make the firms on average worse off. Consider the case when telecommunication firms recognize revenues based on capacity swap. This type of activity (i.e., recognizing assets/revenues under various creative names) can, after all, be detrimental to the industry as a whole when facing tighter scrutiny by creditors. On the other hand, firms in more traditional industries, which are less subject to soft information (e.g. construction, auto, food), are better off with more flexible revenue recognition rule (such as the flexible accounting rules for long term contracts). 


\section{Results on Capital Structure}

Finally, we report on the effect of alternative accounting policies on a firm's capital structure choices. Given that different accounting policies release different information for financial decisions, accounting policies affect capital structure choices. A stringent accounting policy restricts the flow of certain information and thus may cause more or less debt to be used than under an ideal setting. Proposition 4 provides the details of expected debt as a function of accounting policies.

Proposition 4: Assuming $\mathrm{Y}_{\mathrm{L}}<\mathrm{X} / 3$, denote $\mathrm{E}[\mathrm{d} \mid \mathrm{F}]$ the expected debt as a function of accounting policy $\mathrm{F}$, then we have:

(1) if $\mathrm{c} / 2<\mathrm{r}<2 \mathrm{c} / 3$, expected debt under stringent accounting is greater than under flexible accounting, i.e.,

$$
\mathrm{E}\left[\mathrm{d} \mid \mathrm{F}^{\mathrm{S}}\right]=(1-\pi) \mathrm{X}>\mathrm{E}\left[\mathrm{d} \mid \mathrm{F}^{\mathrm{FLEX}}\right]=(1-\rho)(1-\pi) \mathrm{X}+\rho \mathrm{Y}_{\mathrm{L}}
$$

(2) if $\mathrm{c} / 3<\mathrm{r}<\mathrm{c} / 2$, expected debt under stringent accounting is less than under flexible accounting, i.e.,

$$
\mathrm{E}\left[\mathrm{d} \mid \mathrm{F}^{\mathrm{S}}\right]=\mathrm{Y}_{\mathrm{L}}<\mathrm{E}\left[\mathrm{d} \mid \mathrm{F}^{\mathrm{FLEX}}\right]=\rho(1-\pi) X+(1-\rho) \mathrm{Y}_{\mathrm{L}}
$$

It is easy to verify that when debt is relatively inexpensive, or $\mathrm{c} / 2<\mathrm{r}<2 \mathrm{c} / 3$, more debt financing is used under stringent accounting than under full information because less information on the revenue side prevents switching from debt to equity when, in fact, the default risk is high. When debt is relatively expensive, or $\mathrm{c} / 3<\mathrm{r}<\mathrm{c} / 2$, less debt financing is used under stringent accounting because less information prevents switching from equity to debt when the default risk is low. In other words, low risk firms are denied access to credit markets due to lack of accounting flexibility.

Our analysis also points to a link between the information environment and capital structure. A high value of parameter $\pi$ or $\rho$ implies a high likelihood of receiving hard 
information about future cash inflows and outflows, which, in turn, affects expected capital structure because the expected debt is a function of $\pi$ and $\rho$. Under either flexible or stringent accounting, the expected debt level is a decreasing function of $\pi$. This means that when information about future outflow is more difficult obtained relative to information about future inflows (i.e., for a fixed $\rho, \pi$ decreases), debt-financing will more likely be used (consistent with, say, oil and gas companies where, relatively speaking, uncertainties reside mainly on the cost side). When there is more uncertainty about future revenues, equity-financing will more likely be used (consistent with the pharmaceutical or the high-tech industry). ${ }^{28}$

\section{Conclusion}

In this paper we propose an information-economic interpretation of certain features of the accounting measurement apparatus. The primary function of accounting is to convey information to its users. In performing such a conveyance task, certain recognizable accrual accounting features, like flexible or stringent recognition rules, which require deviations from the fair value approach, emerge in response to characteristics of the economic and informational environment. Such features of accounting, in turn, affect firms' real decisions. In this paper, we highlight the inherent/incentive uncertainty in the information environment and the capital structure decision.

In doing so, we focus on the trade-off between flexible rules versus stringent rules. Flexible accounting rules have the advantage of conveying more information. In our model, we emphasize the higher moments of the underlying random variables as the additional information

\footnotetext{
28 Myers (2001), in a concise review of the capital structure literature, supports our predictions with empirical evidence on the financing choices of the oil and gas industry (high debt) and pharmaceutical industry (low debt).
} 
conveyed by flexible rules, and this information is critical for financing decisions (debt or equity choices). Stringent accounting rules have the advantage of fending off managerial abuses of accounting flexibility. We show that, by preventing a firm from making opportunistic reporting choices ex post, the stringent accounting rules cause the firm to be better off ex ante. Such tradeoffs, it seems, also emerge in the current debate over principle-based vs. rule-based accounting standards.

Our study is preliminary, and future studies can expand in either one of two directions: further understanding of how other accounting features affect capital structure, or studying how information demands by debt investors affect accounting. 
Table 1a: Joint Probabilities of $(\mathrm{k}, \delta)$

\begin{tabular}{|l|c|c|c|c|c|}
\hline Prob $(\mathrm{k}, \delta)$ & $\mathrm{k}=0$ & $\mathrm{k}=\mathrm{X} / 3$ & $\mathrm{k}=2 \mathrm{X} / 3$ & $\mathrm{k}=\mathrm{X}$ & Total \\
\hline$\delta=\mathrm{H}$ & 0 & 0 & $.25 \pi$ & $.75 \pi$ & $\pi$ \\
\hline$\delta=\mathrm{M}$ & 0 & $.5 \pi$ & $.5 \pi$ & 0 & $\pi$ \\
\hline$\delta=\mathrm{L}$ & $.75 \pi$ & $.25 \pi$ & 0 & 0 & $\pi$ \\
\hline$\delta=\varnothing$ & $.25(1-3 \pi)$ & $.25(1-3 \pi)$ & $.25(1-3 \pi)$ & $.25(1-3 \pi)$ & $1-3 \pi$ \\
\hline Total & .25 & .25 & .25 & .25 & 1 \\
\hline
\end{tabular}

Table 1b: Joint Probabilities of $\left(y_{2}, \mu\right)$

\begin{tabular}{|l|c|c|c|}
\hline \multicolumn{1}{|c|}{$\operatorname{Prob}\left(\mathrm{y}_{2}, \mu\right)$} & $\mathrm{y}_{2}=\mathrm{Y}_{\mathrm{L}}$ & $\mathrm{y}_{2}=\mathrm{Y}_{\mathrm{H}}$ & Total \\
\hline$\mu=\mathrm{H}$ & $1 / 3 \rho$ & $2 / 3 \rho$ & $\rho$ \\
\hline$\mu=\mathrm{M}$ & $.5 \rho$ & $.5 \rho$ & $\rho$ \\
\hline$\mu=\mathrm{L}$ & $2 / 3 \rho$ & $1 / 3 \rho$ & $\rho$ \\
\hline$\mu=\varnothing$ & $.5(1-3 \rho)$ & $.5(1-3 \rho)$ & $1-3 \rho$ \\
\hline Total & .5 & .5 & 1 \\
\hline
\end{tabular}


Table 3: Accounting Representation of the Underlying Information

\begin{tabular}{|c|c|c|c|}
\hline \multicolumn{2}{|c|}{ Underlying Information } & \multicolumn{2}{|r|}{$\begin{array}{c}\text { Accounting Numbers } \\
\langle\text { rev, exp }\rangle\end{array}$} \\
\hline label & $\langle\mu, \delta\rangle$ & $\begin{array}{c}\text { Cash } \\
\text { Accounting }\end{array}$ & Fair Value Accounting \\
\hline 1 & $\langle\varnothing, \varnothing\rangle$ & $\left\langle\mathrm{y}_{1}, \mathrm{x}_{1}\right\rangle$ & $\left\langle\mathrm{y}_{1}+\mathrm{E}\left[\mathrm{y}_{2}\right], \mathrm{x}_{1}+\mathrm{E}\left[\mathrm{x}_{2}\right]\right\rangle$ \\
\hline 2 & $\langle\varnothing, \mathrm{H}\rangle$ & $\left\langle\mathrm{y}_{1}, \mathrm{x}_{1}\right\rangle$ & $\left\langle\mathrm{y}_{1}+\mathrm{E}\left[\mathrm{y}_{2}\right], \mathrm{x}_{1}+\mathrm{E}\left[\mathrm{x}_{2} \mid \delta=\mathrm{H}\right]\right\rangle$ \\
\hline 3 & $\langle\varnothing, \mathrm{M}\rangle$ & $\left\langle\mathrm{y}_{1}, \mathrm{x}_{1}\right\rangle$ & $\left\langle\mathrm{y}_{1}+\mathrm{E}\left[\mathrm{y}_{2}\right], \mathrm{x}_{1}+\mathrm{E}\left[\mathrm{x}_{2}\right]\right\rangle$ \\
\hline 4 & $\langle\varnothing, \mathrm{L}\rangle$ & $\left\langle\mathrm{y}_{1}, \mathrm{x}_{1}\right\rangle$ & $\left\langle\mathrm{y}_{1}+\mathrm{E}\left[\mathrm{y}_{2}\right], \mathrm{x}_{1}+\mathrm{E}\left[\mathrm{x}_{2} \mid \delta=\mathrm{L}\right]\right\rangle$ \\
\hline 5 & $\langle\mathrm{H}, \varnothing\rangle$ & $\left\langle\mathrm{y}_{1}, \mathrm{x}_{1}\right\rangle$ & $\left\langle\mathrm{y}_{1}+\mathrm{E}\left[\mathrm{y}_{2} \mid \mu=\mathrm{H}\right], \mathrm{x}_{1}+\mathrm{E}\left[\mathrm{x}_{2}\right]\right\rangle$ \\
\hline 6 & $\langle\mathrm{H}, \mathrm{H}\rangle$ & $\left\langle\mathrm{y}_{1}, \mathrm{x}_{1}\right\rangle$ & $\left\langle\mathrm{y}_{1}+\mathrm{E}\left[\mathrm{y}_{2} \mid \mu=\mathrm{H}\right], \mathrm{x}_{1}+\mathrm{E}\left[\mathrm{x}_{2} \mid \delta=\mathrm{H}\right]\right\rangle$ \\
\hline 7 & $\langle\mathrm{H}, \mathrm{M}\rangle$ & $\left\langle\mathrm{y}_{1}, \mathrm{x}_{1}\right\rangle$ & $\left\langle\mathrm{y}_{1}+\mathrm{E}\left[\mathrm{y}_{2} \mid \mu=\mathrm{H}\right], \mathrm{x}_{1}+\mathrm{E}\left[\mathrm{x}_{2}\right]\right\rangle$ \\
\hline 8 & $\langle\mathrm{H}, \mathrm{L}\rangle$ & $\left\langle\mathrm{y}_{1}, \mathrm{x}_{1}\right\rangle$ & $\left\langle\mathrm{y}_{1}+\mathrm{E}\left[\mathrm{y}_{2} \mid \mu=\mathrm{H}\right], \mathrm{x}_{1}+\mathrm{E}\left[\mathrm{x}_{2} \mid \delta=\mathrm{L}\right]\right\rangle$ \\
\hline 9 & $\langle\mathrm{M}, \varnothing\rangle$ & $\left\langle\mathrm{y}_{1}, \mathrm{x}_{1}\right\rangle$ & $\left\langle\mathrm{y}_{1}+\mathrm{E}\left[\mathrm{y}_{2}\right], \mathrm{x}_{1}+\mathrm{E}\left[\mathrm{x}_{2}\right]\right\rangle$ \\
\hline 10 & $\langle\mathrm{M}, \mathrm{H}\rangle$ & $\left\langle\mathrm{y}_{1}, \mathrm{x}_{1}\right\rangle$ & $\left\langle\mathrm{y}_{1}+\mathrm{E}\left[\mathrm{y}_{2}\right], \mathrm{x}_{1}+\mathrm{E}\left[\mathrm{x}_{2} \mid \delta=\mathrm{H}\right]\right\rangle$ \\
\hline 11 & $\langle\mathrm{M}, \mathrm{M}\rangle$ & $\left\langle\mathrm{y}_{1}, \mathrm{x}_{1}\right\rangle$ & $\left\langle\mathrm{y}_{1}+\mathrm{E}\left[\mathrm{y}_{2}\right], \mathrm{x}_{1}+\mathrm{E}\left[\mathrm{x}_{2}\right]\right\rangle$ \\
\hline 12 & $\langle\mathrm{M}, \mathrm{L}\rangle$ & $\left\langle\mathrm{y}_{1}, \mathrm{x}_{1}\right\rangle$ & $\left\langle\mathrm{y}_{1}+\mathrm{E}\left[\mathrm{y}_{2}\right], \mathrm{x}_{1}+\mathrm{E}\left[\mathrm{x}_{2} \mid \delta=\mathrm{L}\right]\right\rangle$ \\
\hline 13 & $\langle\mathrm{~L}, \varnothing\rangle$ & $\left\langle\mathrm{y}_{1}, \mathrm{x}_{1}\right\rangle$ & $\left\langle\mathrm{y}_{1}+\mathrm{E}\left[\mathrm{y}_{2} \mid \mu=\mathrm{L}\right], \mathrm{x}_{1}+\mathrm{E}\left[\mathrm{x}_{2}\right]\right\rangle$ \\
\hline 14 & $\langle\mathrm{~L}, \mathrm{H}\rangle$ & $\left\langle\mathrm{y}_{1}, \mathrm{x}_{1}\right\rangle$ & $\left\langle\mathrm{y}_{1}+\mathrm{E}\left[\mathrm{y}_{2} \mid \mu=\mathrm{L}\right], \mathrm{x}_{1}+\mathrm{E}\left[\mathrm{x}_{2} \mid \delta=\mathrm{H}\right]\right\rangle$ \\
\hline 15 & $\langle\mathrm{~L}, \mathrm{M}\rangle$ & $\left\langle\mathrm{y}_{1}, \mathrm{x}_{1}\right\rangle$ & $\left\langle\mathrm{y}_{1}+\mathrm{E}\left[\mathrm{y}_{2} \mid \mu=\mathrm{L}\right], \mathrm{x}_{1}+\mathrm{E}\left[\mathrm{x}_{2}\right]\right\rangle$ \\
\hline 16 & $\langle\mathrm{~L}, \mathrm{~L}\rangle$ & $\left\langle\mathrm{y}_{1}, \mathrm{x}_{1}\right\rangle$ & $\left\langle\mathrm{y}_{1}+\mathrm{E}\left[\mathrm{y}_{2} \mid \mu=\mathrm{L}\right], \mathrm{x}_{1}+\mathrm{E}\left[\mathrm{x}_{2} \mid \delta=\mathrm{L}\right]\right\rangle$ \\
\hline
\end{tabular}


Table 3a: State-contingent Financing Choices:

Fair Value Accounting with No Inherent Uncertainty

Assume $0<\mathrm{Y}_{\mathrm{L}}<\mathrm{X}, \mathrm{c} / 3<\mathrm{r}<2 \mathrm{c} / 3$

\begin{tabular}{|c|c|c|c|c|c|}
\hline \multirow{2}{*}{\multicolumn{3}{|c|}{$\begin{array}{l}\text { Revenue information: } \mu \\
\text { (probability) }\end{array}$}} & \multicolumn{3}{|c|}{ Expense information: $\delta$ (probability) } \\
\hline & & & $\frac{\operatorname{Exp}=\mathrm{x}_{1}+\mathrm{E}\left[\mathrm{x}_{2} \mid \mathrm{H}\right]}{\mathrm{H}(1 / 3)}$ & $\frac{\operatorname{Exp}=\mathrm{x}_{1}+E\left[\mathrm{x}_{2} \mid \mathrm{M}\right]}{\mathrm{M}(1 / 3)}$ & $\frac{\operatorname{Exp}=x_{1}+E\left[x_{2} \mid L\right]}{L(1 / 3)}$ \\
\hline $\begin{array}{c}\operatorname{Rev}=y_{1}+ \\
E\left[y_{2} \mid H\right]\end{array}$ & \multicolumn{2}{|c|}{$\mathrm{H}(1 / 3)$} & $\begin{array}{l}d=X \\
e=0\end{array}$ & $\begin{array}{l}\mathrm{d}=2 \mathrm{X} / 3 \\
\mathrm{e}=0\end{array}$ & $\begin{array}{l}\mathrm{d}=\mathrm{X} / 3 \\
\mathrm{e}=0\end{array}$ \\
\hline \multirow{2}{*}{$\begin{array}{c}\operatorname{Rev}=y_{1}+ \\
E\left[y_{2} \mid M\right]\end{array}$} & \multirow{2}{*}{$\begin{array}{c}\mathrm{M} \\
(1 / 3)\end{array}$} & $\mathrm{c} / 2<\mathrm{r}$ & $\begin{array}{l}d=X \\
e=0\end{array}$ & $\begin{array}{l}\mathrm{d}=2 \mathrm{X} / 3 \\
\mathrm{e}=0\end{array}$ & $\begin{array}{l}\mathrm{d}=\mathrm{X} / 3 \\
\mathrm{e}=0\end{array}$ \\
\hline & & $\mathrm{r}<\mathrm{c} / 2$ & $\begin{array}{l}d=Y_{L} \\
e=X-Y_{L}\end{array}$ & $\begin{array}{l}\mathrm{d}=\min \left(\mathrm{Y}_{\mathrm{L}}, 2 \mathrm{X} / 3\right) \\
\mathrm{e}=2 \mathrm{X} / 3-\mathrm{d}\end{array}$ & $\begin{array}{l}\mathrm{d}=\min \left(\mathrm{Y}_{\mathrm{L}}, \mathrm{X} / 3\right) \\
\mathrm{e}=\mathrm{X} / 3-\mathrm{d}\end{array}$ \\
\hline $\begin{array}{c}\operatorname{Rev}=\mathrm{y}_{1}+ \\
\mathrm{E}\left[\mathrm{y}_{2} \mid \mathrm{L}\right]\end{array}$ & \multicolumn{2}{|c|}{$\mathrm{L}(1 / 3)$} & $\begin{array}{l}d=Y_{L} \\
e=X-Y_{L}\end{array}$ & $\begin{array}{l}\mathrm{d}=\min \left(\mathrm{Y}_{\mathrm{L}}, 2 \mathrm{X} / 3\right) \\
\mathrm{e}=2 \mathrm{X} / 3-\mathrm{d}\end{array}$ & $\begin{array}{l}\mathrm{d}=\min \left(\mathrm{Y}_{\mathrm{L}}, \mathrm{X} / 3\right) \\
\mathrm{e}=\mathrm{X} / 3-\mathrm{d}\end{array}$ \\
\hline
\end{tabular}

Table 3b: State-contingent Financing Choices:

Fair Value Accounting with Inherent Uncertainty

Assume $0<\mathrm{Y}_{\mathrm{L}}<\mathrm{X}, \mathrm{c} / 3<\mathrm{r}<2 \mathrm{c} / 3$

\begin{tabular}{|c|c|c|c|c|c|}
\hline \multirow{2}{*}{\multicolumn{3}{|c|}{$\begin{array}{l}\text { Revenue information: } \mu \\
\text { (probability) }\end{array}$}} & \multicolumn{3}{|c|}{ Expense information: $\delta$ (probability) } \\
\hline & & & $\frac{\operatorname{Exp}=\mathrm{x}_{1}+\mathrm{E}\left[\mathrm{x}_{2} \mid \mathrm{H}\right]}{\mathrm{H}(\pi)}$ & $\frac{\operatorname{Exp}=\mathrm{x}_{1}+\mathrm{E}\left[\mathrm{x}_{2} \mid \mathrm{M}\right]}{\varnothing \text { or } \mathrm{M}(1-2 \pi)}$ & $\begin{array}{c}\operatorname{Exp}=x_{1}+E\left[x_{2} \mid L\right] \\
L(\pi)\end{array}$ \\
\hline $\begin{array}{c}\operatorname{Rev}=\mathrm{y}_{1}+ \\
\mathrm{E}\left[\mathrm{y}_{2} \mid \mathrm{H}\right]\end{array}$ & \multicolumn{2}{|c|}{$\mathrm{H}(\rho)$} & $\begin{array}{l}d=X \\
e=0\end{array}$ & $\begin{array}{l}d=X \\
e=0\end{array}$ & $\begin{array}{l}\mathrm{d}=\mathrm{X} / 3 \\
\mathrm{e}=0\end{array}$ \\
\hline \multirow{2}{*}{$\begin{array}{c}\operatorname{Rev}=y_{1}+ \\
E\left[y_{2} \mid M\right]\end{array}$} & \multirow{2}{*}{$\begin{array}{l}\varnothing \text { or } \mathrm{M} \\
(1-2 \rho)\end{array}$} & $\mathrm{c} / 2<\mathrm{r}$ & $\begin{array}{l}\mathrm{d}=\mathrm{X} \\
\mathrm{e}=0\end{array}$ & $\begin{array}{l}\mathrm{d}=\mathrm{X} \\
\mathrm{e}=0\end{array}$ & $\begin{array}{l}d=X / 3 \\
e=0\end{array}$ \\
\hline & & $\mathrm{r}<\mathrm{c} / 2$ & $\begin{array}{l}d=Y_{L} \\
e=X-Y_{L}\end{array}$ & $\begin{array}{l}d=Y_{L} \\
e=X-d\end{array}$ & $\begin{array}{l}\mathrm{d}=\min \left(\mathrm{Y}_{\mathrm{L}}, \mathrm{X} / 3\right) \\
\mathrm{e}=\mathrm{X} / 3-\mathrm{d}\end{array}$ \\
\hline $\begin{array}{c}\operatorname{Rev}=\mathrm{y}_{1}+ \\
\mathrm{E}\left[\mathrm{y}_{2} \mid \mathrm{L}\right]\end{array}$ & \multicolumn{2}{|c|}{$\mathrm{L}(\rho 1 / 3)$} & $\begin{array}{l}\mathrm{d}=\mathrm{Y}_{\mathrm{L}} \\
\mathrm{e}=\mathrm{X}-\mathrm{Y}_{\mathrm{L}}\end{array}$ & $\begin{array}{l}d=Y_{L} \\
e=X-d\end{array}$ & $\begin{array}{l}\mathrm{d}=\min \left(\mathrm{Y}_{\mathrm{L}}, \mathrm{X} / 3\right) \\
\mathrm{e}=\mathrm{X} / 3-\mathrm{d}\end{array}$ \\
\hline
\end{tabular}


Table 4: Flexible Accounting Representation of the Underlying Information

\begin{tabular}{|c|c|c|}
\hline \multicolumn{2}{|c|}{ Underlying Information } & Accounting Numbers \\
\hline label & $\langle\mu, \delta\rangle$ & Flexible Accounting \\
\hline 1 & $\langle\varnothing, \varnothing\rangle$ & $\langle 0,0\rangle$ \\
\hline 2 & $\langle\varnothing, \mathrm{H}\rangle$ & $\left\langle\mathrm{y}_{1},\left(\mathrm{x}_{1}+\mathrm{E}\left[\mathrm{x}_{2} \mid \delta=\mathrm{H}\right]\right) \mathrm{k}_{\mathrm{y}}{ }^{*}\right.$ \\
\hline 3 & $\langle\varnothing, \mathrm{M}\rangle$ & $\left\langle\mathrm{y}_{1},\left(\mathrm{x}_{1}+\mathrm{E}\left[\mathrm{x}_{2}\right]\right) \mathrm{k}_{\mathrm{y}}{ }^{\prime} *\right.$ \\
\hline 4 & $\langle\varnothing, \mathrm{L}\rangle$ & $\left\langle\mathrm{y}_{1},\left(\mathrm{x}_{1}+\mathrm{E}\left[\mathrm{x}_{2} \mid \delta=\mathrm{L}\right]\right) \mathrm{k}_{\mathrm{y}}\right\rangle *$ \\
\hline 5 & $\langle\mathrm{H}, \varnothing\rangle$ & $\left\langle\left(\mathrm{y}_{1}+\mathrm{E}\left[\mathrm{y}_{2} \mid \mu=\mathrm{H}\right]\right) \mathrm{k}_{\mathrm{x}}, \mathrm{x}_{1}\right\rangle *$ \\
\hline 6 & $\langle\mathrm{H}, \mathrm{H}\rangle$ & $\left\langle\mathrm{y}_{1}+\mathrm{E}\left[\mathrm{y}_{2} \mid \mu=\mathrm{H}\right], \mathrm{x}_{1}+\mathrm{E}\left[\mathrm{x}_{2} \mid \delta=\mathrm{H}\right]\right\rangle$ \\
\hline 7 & $\langle\mathrm{H}, \mathrm{M}\rangle$ & $\left\langle\mathrm{y}_{1}+\mathrm{E}\left[\mathrm{y}_{2} \mid \mu=\mathrm{H}\right], \mathrm{x}_{1}+\mathrm{E}\left[\mathrm{x}_{2}\right]\right\rangle$ \\
\hline 8 & $\langle\mathrm{H}, \mathrm{L}\rangle$ & $\left\langle\mathrm{y}_{1}+\mathrm{E}\left[\mathrm{y}_{2} \mid \mu=\mathrm{H}\right], \mathrm{x}_{1}+\mathrm{E}\left[\mathrm{x}_{2} \mid \delta=\mathrm{L}\right]\right\rangle$ \\
\hline 9 & $\langle\mathrm{M}, \varnothing\rangle$ & $\left\langle\left(\mathrm{y}_{1}+\mathrm{E}\left[\mathrm{y}_{2}\right]\right) \mathrm{k}_{\mathrm{x}}, \mathrm{x}_{1}\right\rangle^{*}$ \\
\hline 10 & $\langle\mathrm{M}, \mathrm{H}\rangle$ & $\left\langle\mathrm{y}_{1}+\mathrm{E}\left[\mathrm{y}_{2}\right], \mathrm{x}_{1}+\mathrm{E}\left[\mathrm{x}_{2} \mid \delta=\mathrm{H}\right]\right\rangle$ \\
\hline 11 & $\langle\mathrm{M}, \mathrm{M}\rangle$ & $\left\langle\mathrm{y}_{1}+\mathrm{E}\left[\mathrm{y}_{2}\right], \mathrm{x}_{1}+\mathrm{E}\left[\mathrm{x}_{2}\right]\right\rangle$ \\
\hline 12 & $\langle\mathrm{M}, \mathrm{L}\rangle$ & $\left\langle\mathrm{y}_{1}+\mathrm{E}\left[\mathrm{y}_{2}\right], \mathrm{x}_{1}+\mathrm{E}\left[\mathrm{x}_{2} \mid \delta=\mathrm{L}\right]\right\rangle$ \\
\hline 13 & $\langle\mathrm{~L}, \varnothing\rangle$ & $\left\langle\left(\mathrm{y}_{1}+\mathrm{E}\left[\mathrm{y}_{2} \mid \mu=\mathrm{L}\right]\right) \mathrm{k}_{\mathrm{x}}, \mathrm{x}_{1}\right\rangle *$ \\
\hline 14 & $\langle\mathrm{~L}, \mathrm{H}\rangle$ & $\left\langle\mathrm{y}_{1}+\mathrm{E}\left[\mathrm{y}_{2} \mid \mu=\mathrm{L}\right], \mathrm{x}_{1}+\mathrm{E}\left[\mathrm{x}_{2} \mid \delta=\mathrm{H}\right]\right\rangle$ \\
\hline 15 & $\langle\mathrm{~L}, \mathrm{M}\rangle$ & $\left\langle\mathrm{y}_{1}+\mathrm{E}\left[\mathrm{y}_{2} \mid \mu=\mathrm{L}\right], \mathrm{x}_{1}+\mathrm{E}\left[\mathrm{x}_{2}\right]\right\rangle$ \\
\hline 16 & $\langle\mathrm{~L}, \mathrm{~L}\rangle$ & $\left\langle\mathrm{y}_{1}+\mathrm{E}\left[\mathrm{y}_{2} \mid \mu=\mathrm{L}\right], \mathrm{x}_{1}+\mathrm{E}\left[\mathrm{x}_{2} \mid \delta=\mathrm{L}\right]\right\rangle$ \\
\hline
\end{tabular}

$* \mathrm{k}_{\mathrm{x}}=\mathrm{x}_{1} /\left(\mathrm{x}_{1}+\mathrm{E}\left[\mathrm{x}_{2}\right]\right)$ and $\mathrm{k}_{\mathrm{y}}=\mathrm{y}_{1} /\left(\mathrm{y}_{1}+\mathrm{E}\left[\mathrm{y}_{2}\right]\right)$ 
Table 4a: State-contingent Financing Choices: Flexible under Inherent Uncertainty

\begin{tabular}{|c|c|c|c|c|c|}
\hline \multirow{2}{*}{\multicolumn{3}{|c|}{$\begin{array}{l}\text { Revenue information: } \mu \\
\text { (probability) }\end{array}$}} & \multicolumn{3}{|c|}{ Expense information: $\delta$ (probability) } \\
\hline & & & $\begin{array}{c}\begin{array}{c}\exp =0 \text { or } \\
\left(\mathrm{x}_{1}+\mathrm{E}\left[\mathrm{x}_{2} \mid \delta=\mathrm{M}\right]\right) \mathrm{k}_{\mathrm{y}}\end{array} \\
\varnothing \text { or } \mathrm{H}(1-2 \pi)\end{array}$ & $\begin{array}{c}\exp = \\
\left(\mathrm{x}_{1}+\mathrm{E}\left[\mathrm{x}_{2} \mid \delta=\mathrm{M}\right]\right) \mathrm{k}_{\mathrm{y}}\end{array}$ & $\begin{array}{c}\exp = \\
\left(\mathrm{x}_{1}+\mathrm{E}\left[\mathrm{x}_{2} \mid \delta=\mathrm{L}\right]\right) \mathrm{k}_{\mathrm{y}}\end{array}$ \\
\hline $\begin{array}{c}\operatorname{Rev}=y_{1}+ \\
E\left[y_{2} \mid H\right]\end{array}$ & \multicolumn{2}{|c|}{$\mathrm{H}(\rho)$} & $\begin{array}{l}d=X \\
e=0\end{array}$ & $\begin{array}{l}\mathrm{d}=2 \mathrm{X} / 3 \\
\mathrm{e}=0\end{array}$ & $\begin{array}{l}\mathrm{d}=\mathrm{X} / 3 \\
\mathrm{e}=0\end{array}$ \\
\hline \multirow{2}{*}{$\begin{array}{c}\operatorname{Rev}=0 \text { or } \\
\operatorname{Rev}=y_{1}+ \\
E\left[y_{2} \mid M\right]\end{array}$} & \multirow{2}{*}{$\begin{array}{c}\varnothing \text { or } \\
M \\
(1-2 \rho)\end{array}$} & $\mathrm{c} / 2<\mathrm{r}$ & $\begin{array}{l}\mathrm{d}=\mathrm{X} \\
\mathrm{e}=0\end{array}$ & $\begin{array}{l}\mathrm{d}=2 \mathrm{X} / 3 \\
\mathrm{e}=0\end{array}$ & $\begin{array}{l}\mathrm{d}=\mathrm{X} / 3 \\
\mathrm{e}=0\end{array}$ \\
\hline & & $\mathrm{r}<\mathrm{c} / 2$ & $\begin{array}{l}d=Y_{L} \\
e=X-Y_{L}\end{array}$ & $\begin{array}{l}\mathrm{d}=\min \left(\mathrm{Y}_{\mathrm{L}}, 2 \mathrm{X} / 3\right) \\
\mathrm{e}=2 \mathrm{X} / 3-\mathrm{d}\end{array}$ & $\begin{array}{l}\mathrm{d}=\min \left(\mathrm{Y}_{\mathrm{L}}, \mathrm{X} / 3\right) \\
\mathrm{e}=\mathrm{X} / 3-\mathrm{d}\end{array}$ \\
\hline $\begin{array}{c}\operatorname{Rev}=y_{1}+ \\
E\left[y_{2} \mid L\right]\end{array}$ & \multicolumn{2}{|c|}{$\mathrm{L}(\rho)$} & $\begin{array}{l}d=Y_{L} \\
e=X-Y_{L}\end{array}$ & $\begin{array}{l}\mathrm{d}=\min \left(\mathrm{Y}_{\mathrm{L}}, 2 \mathrm{X} / 3\right) \\
\mathrm{e}=2 \mathrm{X} / 3-\mathrm{d}\end{array}$ & $\begin{array}{l}\mathrm{d}=\min \left(\mathrm{Y}_{\mathrm{L}}, \mathrm{X} / 3\right) \\
\mathrm{e}=\mathrm{X} / 3-\mathrm{d}\end{array}$ \\
\hline
\end{tabular}

Table 4b: State-contingent Financing Choices: Flexible under Incentive Uncertainty

\begin{tabular}{|c|c|c|c|c|c|}
\hline \multirow{2}{*}{\multicolumn{3}{|c|}{$\begin{array}{l}\text { Cash Flow information: } \mathrm{y}_{1} \\
\text { (probability) }\end{array}$}} & \multicolumn{3}{|c|}{ Expenses information: exp (probability) } \\
\hline & & & \multirow{2}{*}{$\begin{array}{c}\exp =0 \text { or } \\
\left(\mathrm{x}_{1}+\mathrm{E}\left[\mathrm{x}_{2} \mid \delta=\mathrm{M}\right]\right) \mathrm{k}_{\mathrm{y}} \\
\varnothing \text { or } \mathrm{H} \\
(1-2 \pi)\end{array}$} & \multirow{2}{*}{$\begin{array}{c}\exp = \\
\left(\mathrm{x}_{1}+\mathrm{E}\left[\mathrm{x}_{2} \mid \delta=\mathrm{M}\right]\right) \mathrm{k}_{\mathrm{y}} \\
\mathrm{M} \\
(\pi)\end{array}$} & \multirow{2}{*}{$\begin{array}{c}\exp = \\
\left(\mathrm{x}_{1}+\mathrm{E}\left[\mathrm{x}_{2} \mid \delta=\mathrm{L}\right]\right) \mathrm{k}_{\mathrm{y}} \\
\mathrm{L} \\
(\pi)\end{array}$} \\
\hline & & & & & \\
\hline $\begin{array}{c}\operatorname{Rev}=y_{1}+ \\
E\left[y_{2} \mid H\right]\end{array}$ & \multicolumn{2}{|c|}{$\begin{array}{l}\mathrm{H} \\
(\rho)\end{array}$} & $\begin{array}{l}d=X \\
e=0\end{array}$ & $\begin{array}{l}\mathrm{d}=2 \mathrm{X} / 3 \\
\mathrm{e}=0\end{array}$ & $\begin{array}{l}\mathrm{d}=\mathrm{X} / 3 \\
\mathrm{e}=0\end{array}$ \\
\hline \multirow{2}{*}{$\begin{array}{c}\operatorname{Rev}=y_{1}+ \\
E\left[y_{2} \mid M\right]\end{array}$} & \multirow{2}{*}{$\begin{array}{l}M \\
(\rho)\end{array}$} & $\mathrm{c} / 2<\mathrm{r}$ & $\begin{array}{l}d=X \\
e=0\end{array}$ & $\begin{array}{l}\mathrm{d}=2 \mathrm{X} / 3 \\
\mathrm{e}=0\end{array}$ & $\begin{array}{l}\mathrm{d}=\mathrm{X} / 3 \\
\mathrm{e}=0\end{array}$ \\
\hline & & $\mathrm{r}<\mathrm{c} / 2$ & $\begin{array}{l}d=Y_{L} \\
e=X-Y_{L}\end{array}$ & $\begin{array}{l}\mathrm{d}=\min \left(\mathrm{Y}_{\mathrm{L}}, 2 \mathrm{X} / 3\right) \\
\mathrm{e}=2 \mathrm{X} / 3-\mathrm{d}\end{array}$ & $\begin{array}{l}\mathrm{d}=\min \left(\mathrm{Y}_{\mathrm{L}}, \mathrm{X} / 3\right) \\
\mathrm{e}=\mathrm{X} / 3-\mathrm{d}\end{array}$ \\
\hline \multirow{2}{*}{$\operatorname{Rev}=0$} & \multirow{2}{*}{$\begin{array}{c}\varnothing, L \\
(1-2 \rho)\end{array}$} & $\beta^{\mathrm{S}} \mathrm{c}<\mathrm{r} *$ & $\begin{array}{l}d=X \\
e=0\end{array}$ & $\begin{array}{l}\mathrm{d}=2 \mathrm{X} / 3 \\
\mathrm{e}=0\end{array}$ & $\begin{array}{l}\mathrm{d}=\mathrm{X} / 3 \\
\mathrm{e}=0\end{array}$ \\
\hline & & $\mathrm{r}<\beta^{\mathrm{S}} \mathrm{c} *$ & $\begin{array}{l}d=Y_{L} \\
e=X-Y_{L}\end{array}$ & $\begin{array}{l}\mathrm{d}=\min \left(\mathrm{Y}_{\mathrm{L}}, 2 \mathrm{X} / 3\right) \\
\mathrm{e}=2 \mathrm{X} / 3-\mathrm{d}\end{array}$ & $\begin{array}{l}\mathrm{d}=\min \left(\mathrm{Y}_{\mathrm{L}}, \mathrm{X} / 3\right) \\
\mathrm{e}=\mathrm{X} / 3-\mathrm{d}\end{array}$ \\
\hline
\end{tabular}

$* \beta^{\mathrm{S}}=(1 / 2-5 \rho / 6) /(1-2 \rho) \in(1 / 2,2 / 3)$ 
Table 5: Stringent Accounting Representation of the Underlying Information

\begin{tabular}{|c|c|c|}
\hline \multicolumn{2}{|c|}{ Underlying Information } & Accounting Numbers \\
\hline label & $\langle\mu, \delta\rangle$ & Stringent Accounting \\
\hline 1 & $\langle\varnothing, \varnothing\rangle$ & $\left\langle\mathrm{y}_{1},\left(\mathrm{x}_{1}+\mathrm{E}\left[\mathrm{x}_{2}\right]\right) \mathrm{k}_{\mathrm{y}}\right\rangle^{*}$ \\
\hline 2 & $\langle\varnothing, \mathrm{H}\rangle$ & $\left\langle\mathrm{y}_{1},\left(\mathrm{x}_{1}+\mathrm{E}\left[\mathrm{x}_{2} \mid \delta=\mathrm{H}\right]\right) \mathrm{k}_{\mathrm{y}}\right\rangle *$ \\
\hline 3 & $\langle\varnothing, \mathrm{M}\rangle$ & $\left\langle\mathrm{y}_{1},\left(\mathrm{x}_{1}+\mathrm{E}\left[\mathrm{x}_{2}\right]\right) \mathrm{k}_{\mathrm{y}}\right\rangle^{*}$ \\
\hline 4 & $\langle\varnothing, \mathrm{L}\rangle$ & $\left\langle\mathrm{y}_{1},\left(\mathrm{x}_{1}+\mathrm{E}\left[\mathrm{x}_{2} \mid \delta=\mathrm{L}\right]\right) \mathrm{k}_{\mathrm{y}}\right\rangle^{*}$ \\
\hline 5 & $\langle\mathrm{H}, \varnothing\rangle$ & $\left\langle\mathrm{y}_{1},\left(\mathrm{x}_{1}+\mathrm{E}\left[\mathrm{x}_{2}\right]\right) \mathrm{k}_{\mathrm{y}}\right\rangle^{*}$ \\
\hline 6 & $\langle\mathrm{H}, \mathrm{H}\rangle$ & $\left\langle\mathrm{y}_{1},\left(\mathrm{x}_{1}+\mathrm{E}\left[\mathrm{x}_{2} \mid \delta=\mathrm{H}\right]\right) \mathrm{k}_{\mathrm{y}}\right\rangle *$ \\
\hline 7 & $\langle\mathrm{H}, \mathrm{M}\rangle$ & $\left\langle\mathrm{y}_{1},\left(\mathrm{x}_{1}+\mathrm{E}\left[\mathrm{x}_{2}\right]\right) \mathrm{k}_{\mathrm{y}}\right\rangle^{*}$ \\
\hline 8 & $\langle\mathrm{H}, \mathrm{L}\rangle$ & $\left\langle\mathrm{y}_{1},\left(\mathrm{x}_{1}+\mathrm{E}\left[\mathrm{x}_{2} \mid \delta=\mathrm{L}\right]\right) \mathrm{k}_{\mathrm{y}}\right\rangle^{*}$ \\
\hline 9 & $\langle\mathrm{M}, \varnothing\rangle$ & $\left\langle\mathrm{y}_{1},\left(\mathrm{x}_{1}+\mathrm{E}\left[\mathrm{x}_{2}\right]\right) \mathrm{k}_{\mathrm{y}}\right\rangle^{*}$ \\
\hline 10 & $\langle\mathrm{M}, \mathrm{H}\rangle$ & $\left\langle\mathrm{y}_{1},\left(\mathrm{x}_{1}+\mathrm{E}\left[\mathrm{x}_{2} \mid \delta=\mathrm{H}\right]\right) \mathrm{k}_{\mathrm{y}}\right\rangle *$ \\
\hline 11 & $\langle\mathrm{M}, \mathrm{M}\rangle$ & $\left\langle\mathrm{y}_{1},\left(\mathrm{x}_{1}+\mathrm{E}\left[\mathrm{x}_{2}\right]\right) \mathrm{k}_{\mathrm{y}}\right\rangle^{*}$ \\
\hline 12 & $\langle\mathrm{M}, \mathrm{L}\rangle$ & $\left\langle\mathrm{y}_{1},\left(\mathrm{x}_{1}+\mathrm{E}\left[\mathrm{x}_{2} \mid \delta=\mathrm{L}\right]\right) \mathrm{k}_{\mathrm{y}}\right\rangle^{*}$ \\
\hline 13 & $\langle\mathrm{~L}, \varnothing\rangle$ & $\left\langle\mathrm{y}_{1},\left(\mathrm{x}_{1}+\mathrm{E}\left[\mathrm{x}_{2}\right]\right) \mathrm{k}_{\mathrm{y}}\right\rangle^{*}$ \\
\hline 14 & $\langle\mathrm{~L}, \mathrm{H}\rangle$ & $\left\langle\mathrm{y}_{1},\left(\mathrm{x}_{1}+\mathrm{E}\left[\mathrm{x}_{2} \mid \delta=\mathrm{H}\right]\right) \mathrm{k}_{\mathrm{y}}\right\rangle^{*}$ \\
\hline 15 & $\langle\mathrm{~L}, \mathrm{M}\rangle$ & $\left\langle\mathrm{y}_{1},\left(\mathrm{x}_{1}+\mathrm{E}\left[\mathrm{x}_{2}\right]\right) \mathrm{k}_{\mathrm{y}}\right\rangle^{*}$ \\
\hline 16 & $\langle\mathrm{~L}, \mathrm{~L}\rangle$ & $\left\langle\mathrm{y}_{1},\left(\mathrm{x}_{1}+\mathrm{E}\left[\mathrm{x}_{2} \mid \delta=\mathrm{L}\right]\right) \mathrm{k}_{\mathrm{y}}\right\rangle^{*}$ \\
\hline
\end{tabular}

$* \mathrm{k}_{\mathrm{y}}=\mathrm{y}_{1} /\left(\mathrm{y}_{1}+\mathrm{E}\left[\mathrm{y}_{2}\right]\right)$ 


\section{Table 5a: State-contingent Financing Choices: Stringent}

Assume $0<\mathrm{Y}_{\mathrm{L}}<\mathrm{X}, \mathrm{c} / 3<\mathrm{r}<2 \mathrm{c} / 3$

\begin{tabular}{|c|c|c|c|c|c|}
\hline \multirow{2}{*}{\multicolumn{3}{|c|}{$\begin{array}{l}\text { Cash Flow information: } \mathrm{y}_{1} \\
\text { (probability) }\end{array}$}} & \multicolumn{3}{|c|}{ Expenses information: exp (probability) } \\
\hline & & & \multirow{2}{*}{$\begin{array}{c}\exp = \\
\left(\mathrm{x}_{1}+\mathrm{E}\left[\mathrm{x}_{2} \mid \delta=\varnothing\right]\right) \mathrm{k}_{\mathrm{y}} \\
=\left(\mathrm{x}_{1}+\mathrm{E}\left[\mathrm{x}_{2} \mid \delta=\mathrm{M}\right]\right) \mathrm{k}_{\mathrm{y}} \\
\varnothing \text { or } \mathrm{H} \\
(1-2 \pi)\end{array}$} & \multirow{2}{*}{$\begin{array}{c}\exp = \\
\left(\mathrm{x}_{1}+\mathrm{E}\left[\mathrm{x}_{2} \mid \delta=\mathrm{H}\right]\right) \mathrm{k}_{\mathrm{y}} \\
\mathrm{M} \\
(\pi)\end{array}$} & \multirow{2}{*}{$\begin{array}{c}\exp = \\
\left(\mathrm{x}_{1}+\mathrm{E}\left[\mathrm{x}_{2} \mid \delta=\mathrm{L}\right]\right) \mathrm{k}_{\mathrm{y}} \\
\mathrm{L}(\pi)\end{array}$} \\
\hline & & & & & \\
\hline \multirow{2}{*}{$\begin{array}{l}\text { Rev }=y_{1} \\
+E\left[y_{2}\right]\end{array}$} & \multirow{2}{*}{$\begin{array}{l}\varnothing, \mathrm{H}, \mathrm{M}, \mathrm{L} \\
\quad(1)\end{array}$} & $\mathrm{c} / 2<\mathrm{r}$ & $\begin{array}{l}d=X \\
e=0\end{array}$ & $\begin{array}{l}\mathrm{d}=2 \mathrm{X} / 3 \\
\mathrm{e}=0\end{array}$ & $\begin{array}{l}d=X / 3 \\
e=0\end{array}$ \\
\hline & & $\mathrm{r}<\mathrm{c} / 2$ & $\begin{array}{l}d=Y_{L} \\
e=X-Y_{L}\end{array}$ & $\begin{array}{l}\mathrm{d}=\min \left(\mathrm{Y}_{\mathrm{L}}, 2 \mathrm{X} / 3\right) \\
\mathrm{e}=2 \mathrm{X} / 3-\mathrm{d}\end{array}$ & $\begin{array}{l}\mathrm{d}=\min \left(\mathrm{Y}_{\mathrm{L}}, \mathrm{X} / 3\right) \\
\mathrm{e}=\mathrm{X} / 3-\mathrm{d}\end{array}$ \\
\hline
\end{tabular}




\section{Appendix}

\section{Proof of Lemma 1}

To begin, we prove Lemma 0.

Lemma 0: The optimal financing choices are:

(1) $d^{*}(F(\delta, \mu))$

$=\mathrm{Y}_{\mathrm{L}}+\left(\mathrm{K}(\mathrm{F}(\delta, \mu))-\mathrm{Y}_{\mathrm{L}}\right)\left[\mathrm{I}\left(\mathrm{K}(\mathrm{F}(\delta, \mu))<\mathrm{Y}_{\mathrm{L}}\right)+\mathrm{I}\left(\mathrm{K}(\mathrm{F}(\delta, \mu))>\mathrm{Y}_{\mathrm{L}}\right) \mathrm{I}(\beta(\mathrm{F}(\delta, \mu)) \mathrm{c}<\mathrm{r})\right]$

(2) $\mathrm{e}^{*}(\mathrm{~F}(\delta, \mu))=\mathrm{K}(\mathrm{F}(\delta, \mu))-\mathrm{d}^{*}(\mathrm{~F}(\delta, \mu))$

where $\mathrm{K}(\mathrm{F}(\delta, \mu))=\sup (\mathrm{k} \mid \mathrm{F}(\delta, \mu))$, and $\mathrm{I}($.$) is an indicator function where \mathrm{I}(\mathrm{a})=1$ if a is true and 0 otherwise.

Proof: The operating constraint requires enough funding to cover the highest possible realization of $\mathrm{k}$. Therefore, the size of the funding $\mathrm{K}($.) must be the maximum $\mathrm{k}$ given the information provided by $\mathrm{F}(\delta, \mu)$. So, if $\mathrm{F}(\delta, \mu)$ reveals $\delta$ and $\mu$ truthfully, $\mathrm{K}(\varnothing, \mu)=\mathrm{K}(\mathrm{H}, \mu)=\mathrm{X}$; $\mathrm{K}(\mathrm{M}, \mu)=2 \mathrm{X} / 3$; and $\mathrm{K}(\mathrm{L})=\mathrm{X} / 3$.

The firm may always borrow up to $Y_{L}$, given that a choice of $d=Y_{L}$ is free of bankruptcy. If $\mathrm{K}($.$) is less than \mathrm{Y}_{\mathrm{L}}$, then the firm borrows $\mathrm{K}($.$) and raises no additional equity; if \mathrm{K}($.$) is$ greater than $Y_{L}$ and the expected cost of debt is lower than the cost of equity, the firm borrows $\mathrm{K}($.$) and raises no additional equity; if \mathrm{K}($.$) is greater than \mathrm{Y}_{\mathrm{L}}$ and the expected cost of debt is greater than the cost of equity, the firm borrows $Y_{L}$ and raises the rest with equity.

Applying the formula in Lemma 0 to the special case where $\mathrm{F}(\delta, \mu)=\langle\delta$, $\mu\rangle$, we obtain the optimal choices in Table 2 in Lemma 1. 


\section{Proof of Proposition 1}

First, we prove statement (1). Given the $\operatorname{Prob}(\delta=\varnothing)=\operatorname{Prob}(\mu=\varnothing)=0$, rows labeled 1-5, 9, 13 on Table 3 may be discarded since they represent zero-probability events. With the remaining rows (labeled 6-8, 10-12, and 14-16), it is easy to verify that the $\langle$ rev, exp $\rangle$ is indeed invertible in $\langle\delta, \mu\rangle$.

Statement (2) is a direct consequence of statement (1). Because $\langle$ rev, exp $\rangle$ is invertible in $\langle\delta, \mu\rangle$, knowing $\langle$ rev, exp $\rangle$ is the same as knowing $\langle\delta, \mu\rangle$. Therefore, the optimal choice made knowing $\langle$ rev, exp $\rangle$ must be identical to those knowing $\langle\delta, \mu\rangle$ directly.

Now we prove Statement (3). From Statement (1), we establish that the fair value policy provides the following partition of the set of the states:

$$
\{\{6\},\{7\},\{8\},\{10\},\{11\},\{12\},\{14\},\{15\},\{16\}\}
$$

Suppose the cash accounting can distinguish all other states except states \#8 and \#16. Suppose $\mathrm{d}_{\# 8} *>0, \mathrm{e}_{\# 8} *=0, \mathrm{~d}_{\# 16} *=0, \mathrm{e}_{\# 16} *>0$ because in state $\# 8$, the default risk is lower than in state $\# 16$. So we must have cost of debt in state $\# 8\left(\mathrm{c} \beta_{\# 8}\right)$ less than the cost of equity $(\mathrm{r}): \mathrm{c} \beta_{\# 8} *<\mathrm{r}$. Similarly, $\mathrm{c} \beta_{\# 16} *>\mathrm{r}$. The expected cost of capital for these two states is $\operatorname{Prob}(\# 8) \mathrm{c} \beta_{\# 8} *+$ Prob(\#16) r. Under fair value accounting, each state is perfectly revealed by the accounting numbers, so the firm can achieve this expected cost of capital. However, since cash accounting does not distinguish these two states, debt or equity choices are made based on the expectation over these two states. Suppose under cash accounting, $\mathrm{d}_{\{\# 8, \# 16\}} *>0$ and $\mathrm{e}_{\{\# \#, \# 16\}} *=0$, then we must have the expected cost of capital as $\operatorname{Prob}(\# 8) \mathrm{c} \beta_{\# 8} *+\operatorname{Prob}(\# 16) \mathrm{c} \beta_{\# 16}{ }^{*}$, which is more than that under fair value accounting. Suppose, instead $\mathrm{d}_{\{\# 8, \# 16\}} *=0$ and $\mathrm{e}_{\{\# 8, \# 16\}} *>0$, then we must have the expected cost of capital to be Prob(\#8) r + Prob(\#16) r, which is also more than that 
under fair value accounting. Given that the two methods provide the same information and therefore the same capital choices in all other states, we conclude that fair value accounting is preferred to cash accounting. If the cash flow accounting cannot distinguish any other pair of states in (A1), one can make an argument similar to states 8 and 16 example above. This is because any pair will induce different default risk $(\beta)$ or total funding need $(\mathrm{K})$.

\section{Proof of Proposition 2}

Regarding statement (1), examining Table 4 indicates that under the flexible policy, $\langle$ rev, $\exp \rangle$ is in fact invertible in $\langle\delta, \mu\rangle$ as long as $E\left[\mathrm{x}_{2} \mid \delta\right]$ and $E\left[\mathrm{y}_{2} \mid \mu\right]$ are never zero, which is the case by assumption. Similarly, statement (2) is a direct consequence of statement (1).

Note we prove statement (3), i.e, the flexible policy is strictly preferred to the fair Value policy. Comparing Table 3 and Table 4, we establish that the flexible accounting policy provides a finer partition of the set of the states. To illustrate, we denote the sixteen possible states by the label number in Table 3 . So, the set of possible states is

$$
\mathrm{S}=\{1,2,3,4,5,6,7,8,9,10,11,12,13,14,15,16\}
$$

Statement (1) in proposition 2 is equivalent to the statement that the flexible accounting provides the following partition of $\mathrm{S}$.

$$
\{\{1\},\{2\},\{3\},\{4\},\{5\},\{6\},\{7\},\{8\},\{9\},\{10\},\{11\},\{12\},\{13\},\{14\},\{15\},\{16\}\} .
$$

And Table 3 shows that fair value accounting provides the following partition of S.

$$
\{\{1,3,9,11\},\{2,10\},\{4,12\},\{5,7\},\{6\},\{8\},\{13,15\},\{14\},\{16\}\} .
$$

From here all we need to show is that there exists at least one state $\left\langle\delta^{\prime}, \mu^{\prime}\right\rangle$ such that $\operatorname{EV}\left(\Omega=\left\langle\mathrm{x}_{1}\right.\right.$, $\left.\left.\mathrm{y}_{1}, \mathrm{~F}^{\mathrm{FLEX}}\left(\delta^{\prime}, \mu^{\prime}\right)\right\rangle\right)>\mathrm{EV}\left(\left\langle\mathrm{x}_{1}, \mathrm{y}_{1}, \mathrm{~F}^{\mathrm{FV}}\left(\delta^{\prime}, \mu^{\prime}\right)\right\rangle\right)$. Consider the state $\langle\delta=\mathrm{M}, \mu\rangle$ as an example, given the hypothesis in the statement (3) in proposition $1: \sup (\mathrm{k} \mid \delta=\mathrm{M})<\mathrm{Y}_{\mathrm{L}}<\sup (\mathrm{k})<\mathrm{Y}_{\mathrm{H}}$. We know the 
default risk in this state is zero: $\beta(\delta=\mathrm{M}, \mu)=0$ because the lowest $\mathrm{y}_{2}$ is greater than the highest $\mathrm{k}$. In other words, the firm can always pay for a second period loan. As a result, knowing the true state $(\delta=M, \mu)$, debt financing is the obvious choice: $\mathrm{d}^{*}(\delta=\mathrm{M}, \mu)=\mathrm{Q}^{*}(\delta=\mathrm{M}, \mu)=\sup (\mathrm{k} \mid \delta=\mathrm{M})=$ $2 \mathrm{X} / 3$ and $\mathrm{e}^{*}(\delta=\mathrm{M}, \mu)=0$.

Under the flexible policy, these ideal choices are made because knowing the revenue and expenses is the same of knowing $\langle\delta, \mu\rangle$ (recall by statement (1), $\langle$ rev, exp $\rangle$ are invertible in $\langle\delta$, $\mu\rangle)$. Under the fair value rules, the state $\langle\delta=\mathrm{M}, \mu\rangle$ is pooled with the state $\langle\delta=\varnothing, \mu\rangle$. So, the assessed default risk is no longer zero, $\beta\left(\mathrm{F}^{\mathrm{FV}}(\delta=\mathrm{M}, \mu)\right)>0$. Depending on the parameter value, equity may be used (if $\mathrm{r}<\beta\left(\mathrm{F}^{\mathrm{FV}}(\delta=\mathrm{M}, \mu)\right)$ c) or debt may be used (if $\left.\mathrm{r}>\beta\left(\mathrm{F}^{\mathrm{FV}}(\delta=\mathrm{M}, \mu)\right) \mathrm{c}\right)$. Either way, capital is more costly than in the case of the flexible policy. So, here the flexible policy is strictly preferred to the fair value policy.

\section{Proof of Proposition 3}

Assume $\mathrm{Y}_{\mathrm{L}}<\sup (\mathrm{k} \mid \delta=\mathrm{L})=\mathrm{X} / 3$. This implies that default risk is non-zero for all states because the only way to stay solvent is $y_{2}=Y_{H}$. In the presence of incentive uncertainty, the manager would choose the following reporting strategy

$$
\operatorname{rev}= \begin{cases}y_{1}+E\left[y_{2} \mid \mu\right] & \text { if } \mu=H, \text { or } M \\ y_{1} & \text { if } \mu=L \text { or } \varnothing .\end{cases}
$$

The banker would assess default risk as follows 
Default Risk $=\left\{\begin{array}{cl}\beta(\delta, \mu) & \text { if rev }=y_{1}+E\left[y_{2} \mid \mu\right], \text { for } \mu=M, H, \\ \beta^{*}=\frac{(1-3 \rho) \beta(\delta, \mu=\phi)+\rho \beta(\delta, \mu=L)}{(1-3 \rho)+\rho} & \text { if rev }=y_{1} .\end{array}\right.$

Condition $\beta^{*} \mathrm{c}<\mathrm{r}$ ensures that the manager can benefit from pooling with $\mu=\varnothing$ when, in fact, $\mu=\mathrm{L}$ because the resulting financing cost is less than the cost of equity capital $\mathrm{r}$. (In cases when $\mu=\mathrm{M}$ or when $\mu=\mathrm{H}$, reporting $\mu=\varnothing$ would only increase the assessed default risk and increase the financing cost. The manager, therefore, would not have an incentive to misreport.)

To show when the firm may benefit ex ante by committing to a stringent recognition policy, we start with comparing $\mathrm{V}\left(\mathrm{F}^{\mathrm{FLEX}}\right.$, incentive) with $\mathrm{V}\left(\mathrm{F}^{\mathrm{S}}\right)$, where $\mathrm{V}\left(\mathrm{F}^{\mathrm{FLEX}}\right.$, incentive $)$ denotes the ex ante NPV of the project based on the optimal debt-equity choices according Table $4 \mathrm{~b}$, and $\mathrm{V}\left(\mathrm{F}^{\mathrm{S}}\right)$ based on Table 5a, similarly. Then we have

$$
\begin{aligned}
\mathrm{V}\left(\mathrm{F}^{\mathrm{FLEX}}, \text { incentive }\right)=\sum_{\delta \mu} \operatorname{EV}\left(\mathrm{F}^{\mathrm{FLEX}}(\delta, \mu) \text { incentive }\right) \\
=\sum_{\delta \mu} \operatorname{EV}\left(\mathrm{F}^{\mathrm{S}}(\delta, \mu)\right) \\
+3 \rho\left(\mathrm{r}-\mathrm{c} \beta^{*}\right)((1-2 \pi) \mathrm{X}+\pi 2 \mathrm{X} / 3+\pi \mathrm{X} / 3) \\
-(1-3 \rho)\left(\mathrm{c} \beta^{*}-\mathrm{c} / 2\right)((1-2 \pi) \mathrm{X}+\pi 2 \mathrm{X} / 3+\pi \mathrm{X} / 3) \\
=\mathrm{V}\left(\mathrm{F}^{\mathrm{S}}\right)+\left[\rho\left(\mathrm{r}-\mathrm{c} \beta^{*}\right)-(1-3 \rho)\left(\mathrm{c} \beta^{*}-\mathrm{c} / 2\right)\right](1-\pi) \mathrm{X}
\end{aligned}
$$

From here, observe that if $\rho$ is sufficiently small, $\mathrm{V}\left(\mathrm{F}^{\mathrm{S}}\right)>\sum_{\delta \mu} \operatorname{EV}\left(\mathrm{F}^{\mathrm{FLEX}}(\delta, \mu)\right.$ incentive $)$. So, the firm will be better off, ex ante, by committing to a stringent recognition policy.

\section{Proof of Proposition 4}

The expected debt level given in proposition 4 is calculated based on Tables $4 \mathrm{a}$ and $5 \mathrm{a}$. The optimal choices in these two tables are calculated using Lemma 0, which is stated and proved in the proof of Lemma 1. 


\section{Reference}

American Institute of Certified Public Accountants. 1981. Statement of Position 81-1: Accounting for Performance of Construction-Type and Certain production-Type Contracts. New York, NY: American Institute of Certified Public Accountants.

Antle, R., and J. S. Demski. 1989. Revenue Recognition. Contemporary Accounting Research 5 (2):423-451.

Arya, A., J. Glover, and S. Sunder. 1998. Earnings Management and the Revelation Principle. Review of Accounting Studies 3 (1-2):7-34.

Baiman, S. 1975. The Evaluation and Choice of Internal Information Systems Within a Multiperson World. Journal of Accounting Research 13:1-15.

Baxter, N. 1967. Leverage, Risk of Ruin and the Cost of Capital. Journal of Finance 22 (September): 395-403.

Brown, D. 1966. Cost of Imposing Uniform Accounting Practices. Financial Executive, March: 38-44.

Catlett, G. 1964. Controversy over Uniformity of Accounting Principles. The Journal of Accountancy, December: 37-43.

Chen A. 1979. A Theory of Corporate Bankruptcy and Optimal Capital Structure. In J. Bicksler (ed.) Handbook of Financial Economics. Amsterdam: North-Holland.

Christensen, J. and J. Demski. 2002. Accounting Theory: An Information Content Perspective. McGraw-Hill.

Christensen, P., and G. Feltham. 2003. Economics of Accounting. Vol. I, Kluwer Series in Accounting Scholarship. Norwell, MA.

Demski, J. S., and G. Feltham. 1976. Cost Determination: A Conceptual Approach. Iowa City, Iowa: Iowa State University Press.

Demski, J. S., and D. Sappington. 1990. Fully Revealing Income Measurement. Accounting Review 65 (2):363-383.

Dutta, S., and S. Reichelstein. 1999. Asset Valuation and Performance Measurement in a Dynamic Agency Setting. Review of Accounting Studies 4 (3/4):235-258.

Dutta, S., and X. Zhang. 2002. Revenue Recognition in a Multiperiod Agency Model. Journal of Accounting Research, March: 67-83.

Dye, R. 1985. Disclosure of Nonproprietary Information. Journal of Accounting Research:123145.

Dye, R., and R. Verrecchia. 1995. Discretion vs. Uniformity: Choices among GAAP. Accounting Review 70 (3):389-415.

Estes, R., and H. Brown. 1966. Comparability and Flexibility: A Proposed Solution to the Uniformity Dilemma. Financial Analysts Journal, May-June: 65-68.

Financial Accounting Standards Board. 1984. Statement of Financial Accounting Standards No.5. Recognition and Measurement in Financial Statements of Business Enterprises. Norwalk, CT: Financial Accounting Standards Board.

Financial Accounting Standards Board. 2004. Fair Value Measurements (Proposed Statement of Financial Accounting Standards). Norwalk, CT: Financial Accounting Standards Board.

Gjesdal, F., and R. Antle. 2001. Dividend Covenants and Income Measurement. Review of Accounting Studies 6 (1):53-75. 
Hart, O. 1995. Firms, Contracts, and Financial Structure. London: Oxford University Press. Ijiri, Yuji.1975. Theory of Accounting Measurement, Studies in Accounting Research \#10. Sarasota, FL: American Accounting Association.

Jennings, R. W., H. Marsh, J. Coffee, and Joel Seligman.1998. Securities Regulation. New York, NY: Foundation Press.

Johnson, L. T., and R. K. Storey. 1982. Recognition in Financial Statements: Underlying Concepts and Practical Conventions. Stamford, CT: Financial Accounting Standards Board.

Kanodia, C. 1980. Effects of Shareholder Information on Corporate Decisions and Capital Market Equilibrium. Econometrica 48 (4):923-953.

Kirschenheiter, M. 1999. Optimal Contracting, Accounting Standards, and Market Structures. Contemporary Accounting Research 16 (2):243-276.

Kirschenheiter, M. 2002. Representational Faithfulness in Accounting: A Model of Hard Information. Working paper, Columbia University.

Kraus, A., and R. Litzenberger. 1973. A State Preference Model of Optimal Financial Leverage. Journal of Finance (September): 911-21.

Liang, P. 2000. Accounting Recognition, Moral Hazard, and Communications. Contemporary Accounting Research 17 (3):457-490.

Miller, M., and F. Modigliani. 1958. The Cost of Capital, Corporation Finance, and the Theory of Investment. American Economic Review 48 (June):261-297.

Myers, S. C. 2001. Capital structure. Journal of Economic Perspectives 15 (2):81-102.

Myers, S. C. and N. Majluf. 1984. Corporate Financing and Investment Decisions When Firms Have Information That Investors Do Not Have. Journal of Financial Economics 13: 187-221.

Ohlson, James, and X. Zhang. 1998. Accrual Accounting and Equity Valuation. Journal of Accounting Research 36 (Supplement):85-111.

Pacharn, P. 2003 Selectivity, Consistency, and Accounting Method Choice. SUNY Buffalo working paper.

Paton, W. A. 1962. Accounting theory: Accounting Studies Press, Ltd. Original edition, New York, NY: Ronald Press, 1922.

Paton, W. A., and A. C. Littleton. 1940. An introduction to corporate accounting standards. Sarasota, FL: American Accounting Association.

Reichelstein, S. 1997. Investment Decisions and Managerial Performance Evaluation. Review of Accounting Studies 38 (2):243-269.

Rogerson, W. 1997. Intertemporal Cost Allocation and Managerial Investment Incentives: A Theory Explaining the Use of Economic Value Added as a Performance Measure. The Journal of Political Economy 105 (4):770-795.

Securities and Exchange Commission. 1999. SEC Staff Accounting Bulletin: No. 101 Revenue Recognition in Financial Statements. URL: http://www.sec.gov/interps/account/sab101.htm.

Sunder, S. Theory of Accounting and Control. Cincinnati, OH: Thomson Press, 1997.

Trueman, B., and S. Titman. 1988. An Explanation of Accounting Income Smoothing. Journal of Accounting Research, 26 (supp): 127 